\title{
How many large camelids in the world? A synthetic analysis of the world camel demographic changes
}

\author{
B. Faye $e^{1,2}$ (D)
}

\begin{abstract}
At world level, the current official number of large camelids cannot be determined exactly (it is estimated to be more than 35 million heads), and the role of camels in the livestock economy is highly variable. The only reliable statistics are provided by FAO since 1961. According to these data, five different patterns of demographic changes have been observed. In countries marked by a regular or drastic decline of their camelid population, a tendency to re-increase has been in force since the beginning of the century, except in India. Generally, countries marked by a sharp recent increase in their large camelid population have implemented a census and readjusted their data. Many inconsistencies occur in available data, most notably cases arising from changes occurring in state status (for example secession of Eritrea, Soviet Union collapse). Moreover, large camelid stocks in Australia, in countries of new camel establishment (Western countries) and those related to the expansion of camel farming, notably in Africa, are not recorded in the international database. In addition, there is no distinction between dromedary and Bactrian data. The present large camelid population in the world is probably more than 40 million and could reach 60 million after 25 years from now if the current demographic trend is maintained.
\end{abstract}

Keywords: Camel population, Dromedary, Bactrian, Demography, Tropical livestock unit, FAO, Census

\section{Introduction}

The question in connection with the exact number of large camelid heads in the world is often repeatedly asked. In scientific literature, authors usually do not hesitate referring to the official website of FAOSTAT (Faye and Bonnet 2012). But, in some cases, the number given is not updated, and the reliability of this number never challenged. Moreover, when the same authors give the national statistics on their respective country, the gap between FAO data and national information is not also addressed. In fact, within a country, statistical data also vary according to sources or institutions. Finally, a total confusion occurs, and it is quite difficult to have a

\section{Correspondence: bjfaye50@gmail.com}

The author has recently published a book with Pr Mohammed Bengoumi on "Camel hematology and clinical biochemistry" (Springer Pub., 2018).

${ }^{1}$ UMR SELMET, CIRAD-ES, 34398 Montpellier Cedex, France

${ }^{2}$ International Independent Camel Expert, Al-Farabi Kazakh National University, 050040 Almaty, Kazakhstan clear picture of the current camel population in the world. In the last available FAOSTAT database (year 2018), among the 46 national entities declaring a camel population, only $50 \%$ are the official data provided by the national ministries, and the remainder is based on FAO's estimates. The present paper aims at proposing a critical review of the available information on the camel population worldwide and of its demographic changes. It is important to note beforehand that the available information does not make a distinction between the onehumped dromedary camel (Camelus dromedarius) and the double-humped Bactrian camel (Camelus bactrianus). In the rest of the paper, the term "camel" will refer to large camelids in general, knowing that the two species are geographically separated with a few exceptions. The present review focuses on domestic large camelids and will not integrate the wild camel (Camelus bactrianus ferus) living in remote desert areas between China

\section{SpringerOpen}

(c) The Author(s). 2020 Open Access This article is licensed under a Creative Commons Attribution 4.0 International License, which permits use, sharing, adaptation, distribution and reproduction in any medium or format, as long as you give appropriate credit to the original author(s) and the source, provide a link to the Creative Commons licence, and indicate if changes were made. The images or other third party material in this article are included in the article's Creative Commons licence, unless indicated otherwise in a credit line to the material. If material is not included in the article's Creative Commons licence and your intended use is not permitted by statutory regulation or exceeds the permitted use, you will need to obtain permission directly from the copyright holder. To view a copy of this licence, visit http://creativecommons.org/licenses/by/4.0/. 
and Mongolia. The number of this protected species is estimated between 1000 and 1600 heads (Burger et al. 2019).

\section{Official data on "camel countries"}

There are, officially, 46 national entities in the world declaring camel stock. Among them, 20 countries are in Africa, ${ }^{1} 25$ in Asia and one in Europe (Ukraine ${ }^{2}$ ). Regarding the geographical distribution of the two involved species, only dromedaries are found in African countries and in Near and Middle Eastern and Southern Asian countries, and only Bactrians inhabit Central Asia. The two species, however, are cohabiting in a few countries only, mainly in Kazakhstan (Map 1). In 1961, these national entities amounted to 38 countries only, because the former Soviet Union included all the Central Asian states and Ethiopia included Eritrea. Moreover, Namibia has emerged as a new camel country only since the 2000 s. Globally, $70 \%$ of the African countries' data and $42 \%$ of Asian countries' data are based on estimates because of lack of readily available livestock census. For the most recent data available in 2018, the total number of camels recorded in the world was 35,525,270 (FAOSTAT 2020). In 1961, date of the first available data, $60 \%$ of the 38 national entities declared official data. The total camel population at that time was assessed to stand at 12,926,638 heads. The annual growth of world camel population was estimated at $3.07 \%$ but with contrasting national results varying between $-1.95 \%$ (Kyrgyzstan, calculated right from independence in 1992) and $+45.3 \%$ (Oman, calculated from 1961). Globally, $35 \%$ of the national entities recorded a negative growth rate (Table 1). A mean growth of more than $10-15 \%$ cannot be maintained without import of live animals as the natural growth of a camel herd can be estimated as approximately from 5 to 10\% (Bonnet 1996; Adamou 2008).

\section{Typology of demographic growth}

A data table ( $i, j)$ including the 38 national entities recorded in 1961 (i) and their annual camel population from 1961 to 2018 (j) was created from the FAO database. To compare growth regardless of the size of the camel population, a new data table of growth index was calculated by using the index 100 in 1961 . The annual index was calculated as follows:

Index $=$ camel population at the year $\mathrm{Y} /$ camel population in $1961 \times 100$

In order to identify different types of growth between 1961-2018, an automatic cluster analysis (Ascending Hierarchical Classification -AHC) was used (Everitt et al. 2001).

\footnotetext{
${ }^{1}$ The entity "Western Sahara" recorded in FAO database being included in Morocco.

${ }^{2}$ However, the camel population in Ukraine is concentrated in Crimea, at present included in Russia.
}

Cluster analysis allowed the grouping of countries with comparable chronicles. Finally, five types of camel population growth were identified with the following patterns:

- Camel countries with a negative growth $(n=15)$. Mean annual decline of camel population was $0.85 \%$ (Fig. 1a). This includes Asian countries (China, India, Mongolia, Afghanistan), Near Eastern countries (Iran, Iraq, Israel, Jordan, Lebanon, Kuwait, Turkey), North African countries (Egypt, Libya, Morocco without Western Sahara) and Senegal. The most important decline was observed in Turkey $(-1.7 \%$ year), where the camel population witnessed a steep decrease from 65,390 heads in 1961 to 1703 in 2018.

- Camel countries with slight regular increase $(n=12)$. With a mean increase of $1.77 \%$ /year (range $0.46-$ 3.02\%), the camel population has doubled since 1961 (Fig. 1b). It includes northern and western part of Africa (Algeria, Tunisia, South Morocco as former Western Sahara, Mauritania, Burkina Faso) and the Horn of Africa (Sudan, Ethiopia, Somalia). In Asia, only Pakistan, Bahrain and Central Asian countries (former USSR and all new independent states) are included.

- Camel countries with a rapid growth after decline $(n=2)$. With $6.05 \%$ of mean annual growth, Syria and United Arab Emirates witnessed a relatively fast period of growth in 1990 after a significant decline (Fig. 1c).

- Camel countries with sharp increase of camel population following a regular growth $(n=8)$. The annual growth is $18.9 \%$ with a sharp increase commencing suddenly in the years 2013/2014 (Fig. 1d). The population has multiplied by factor of 12 in 57 years. This ascending growth pattern is clearly noticeable mainly in the Sahel countries and Horn of Africa (Mali, Niger, Chad, Nigeria, as well as Kenya and Djibouti) but also in Qatar and Saudi Arabia.

- Camel growth with a sudden increase after 2012 in Sultanate of Oman (Fig. 1e). The camel population after an important sustained growth period from 1976 to 2012 almost doubled going from 134,800 heads in 2012 to 242,833 heads in 2013 (official data). It is noteworthy that the numbers of imported camels in 2012 and 2013 were 5180 and only seven heads respectively, which cannot fully account for the sudden spike in camel population observed in this country.

However, the weight of each pattern is not similar in the demographic changes. The pattern type 4 represented only less than $10 \%$ of the camel population in 


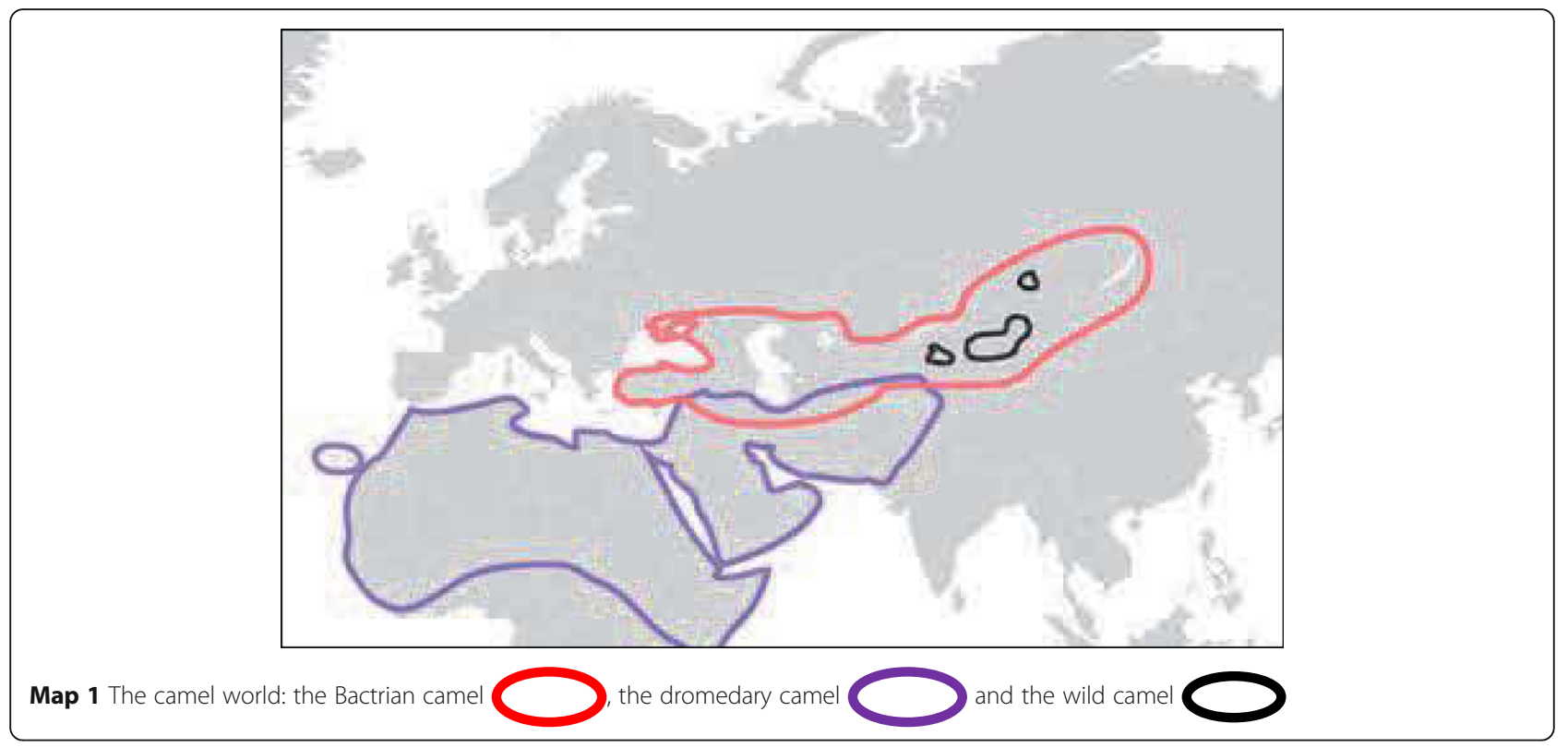

1961 and accounted for more than 40\% in 2018 (Table 2). Instead, countries with pattern type 1 recorded a decline ranging from 28.1 to $5.1 \%$ of the camel population. Pattern 2 (i.e. demographic change marked by a regular growth), though dominant in 1961, still represented more than $50 \%$ of the population in 2018 .

\section{The place of large camelids in the livestock economy}

To assess the weight of camels in the livestock economy, the number of camel heads is compared to the total number of tropical livestock units (TLU). This parameter is defined as a live weight of $250 \mathrm{~kg}$. There are different conversion factors used in the literature, but globally, camel equals on average 1 TLU while buffalo is 0.9 , cow 0.7 , horse 1.0 , mule 0.5 and sheep and goats 0.1 (Jahnke 1982). Between 1961 and 2018, the percentage of camel TLU among livestock went from 2.8 to $4.4 \%$ in the camel countries although the increase of camel population is observed in $37 \%$ only of those countries. In 1984, Wilson classified camel countries based on the percentage of camels in domestic herbivorous biomass (DHB), a similar indicator to TLU (Wilson 1984). Similarly, five types of camel countries can be noted (Fig. 2):

- Countries with a marginal place of camel livestock (less than 1\% of TLU). This encompasses Russia and all Central Asian countries which were part of the former Soviet Union (i.e. countries with Bactrian camels), except Kazakhstan. It also includes countries where camel farming is in steep decline (Turkey, Lebanon) or countries on the fringes of camel distribution area (Senegal, Burkina Faso). In addition, it includes large countries with limited percentage of arid areas in their territory (China, India). The minimum is observed in Turkey (0.01\%).

- Countries with a low proportion of camel livestock (1-5\% of TLU). It includes part of Maghreb (northern part of Morocco, Egypt), other African countries with sizeable cattle and small ruminants stock (Nigeria, Ethiopia), Asian countries in Near and Middle East (Israel, Jordan, Syria, Iraq, Iran, Pakistan and Afghanistan) and Mongolia.

- Countries with a medium proportion of camel livestock (5-15\% of TLU). In this group, countries of the Maghreb (Algeria, Tunisia, Libya), Sahel and East Africa (Mali, Niger, Sudan, Kenya) and Arabian Peninsula (Bahrain, Kuwait, Yemen) can be found.

- Countries with a high proportion of camel livestock (15-35\% of TLU). This group involves three African countries (Mauritania, Chad and Djibouti) and two countries of the Arabian Peninsula (Saudi Arabia and Oman).

- Countries with an extremely lofty proportion of camel livestock (more than 35\%). Somalia, United Arab Emirates, Qatar and South-Morocco belong to this group with a maximum of $83.7 \%$ in the last entity.

In most cases, increasing contribution of camel stock in the total TLU since 1961 has been occurring in countries that have already a high proportion of camels (Fig. 2). The countries where the proportion of camel stock increased exponentially are Qatar (+17.1\%), Oman (+16.8\%), 
Table 1 Classification of the camel countries and national entities according to their mean growing annual growth (calculated from FAOStat 2020)

\begin{tabular}{|c|c|c|c|}
\hline \multicolumn{2}{|l|}{ Negative growth } & \multicolumn{2}{|l|}{ Positive growth } \\
\hline Country & Ann. growth & Country & Ann. growth \\
\hline Kyrgyzstan & -1.95 & Ukraine & 0.07 \\
\hline Turkey & -1.71 & USSR & 0.46 \\
\hline Russia & -1.64 & Tunisia & 0.66 \\
\hline Lebanon & -1.48 & Namibia & 0.68 \\
\hline Morocco (without Sahara) & -1.31 & Azerbaijan & 0.75 \\
\hline Libya & -1.29 & Eritrea & 0.84 \\
\hline India & -1.15 & Bahrain & 0.98 \\
\hline Iraq & -1.06 & Tajikistan & 1.00 \\
\hline Iran & -0.89 & Senegal & 1.12 \\
\hline Mongolia & -0.82 & Burkina Faso & 1.13 \\
\hline Israel & -0.67 & Ethiopia & 1.34 \\
\hline Jordan & -0.60 & Pakistan & 1.39 \\
\hline Afghanistan & -0.55 & Kazakhstan & 1.66 \\
\hline Uzbekistan & -0.28 & Yemen & 1.98 \\
\hline China & -0.27 & Wsahara & 2.18 \\
\hline Egypt & -0.24 & Sudan & 2.52 \\
\hline \multirow[t]{16}{*}{ Kuwait } & -0.10 & Somalia & 2.63 \\
\hline & & Algeria & 3.00 \\
\hline & & Mauritania & 3.02 \\
\hline & & Djibouti & 5.16 \\
\hline & & Syria & 5.82 \\
\hline & & UAE & 6.27 \\
\hline & & Niger & 7.10 \\
\hline & & Turkmenistan & 8.05 \\
\hline & & Saudi Arabia & 9.01 \\
\hline & & Mali & 11.67 \\
\hline & & Ethiopia & 11.77 \\
\hline & & Kenya & 14.65 \\
\hline & & Qatar & 26.50 \\
\hline & & Nigeria & 33.76 \\
\hline & & Chad & 43.64 \\
\hline & & Oman & 45.29 \\
\hline
\end{tabular}

Somalia (+ 14.7\%), Chad $(+13.8 \%)$ and Mauritania (+ $10.9 \%)$. Globally, the proportion of camel TLU increased in all African countries (from Mauritania to Somalia), where severe droughts have occurred. After devastating droughts occurring at the end of the twentieth century, cattle breeders in most of the affected countries started adopting camels as part of their livelihood strategy, leading to a decline of their cattle economy (Jones and Thornton 2009). For example, in Mauritania (Fig. 3), the cattle number declined from 2,150,000 heads in 1961 to $1,910,000$ heads in 2018 while the number of camels increased from 550,000 to 1,500,000 heads (Fig. 4). In Kenya and Ethiopia, Borana people, traditionally cattle breeders, changed their preference from cattle to camel rearing (Kagunyu and Wanjohi 2014). In various parts of Ethiopia (Afar and Somali states), the camel population increased between + 16.5 and $+1203 \%$ during the period 1997-2011, while at the same time, cattle population decreased between -8.2 and $-36.2 \%$ (Yosef et al. 2013). The shift from cattle to camels is an adaptation for a better social-ecological resilience in pastoralist community (Volpato and King 2019).

\section{The end of the decline in countries of pattern 1?}

If the worldwide camel population is still growing, the group of countries with a declining population (pattern 1) represents an important part of the countries (40\%), even if their contribution to the whole population is becoming low (5.1\%, Table 2). However, on average, the decline appears to have stopped since the 2000s (Fig. 1a). Indeed, within this pattern, different demographic changes are observed. For such a comment, the comparison between China and India is informative (Fig. 5): while the Indian dromedary camel population is still in decline, especially since the 2010s, a reverse trend developed in China. After a long decline since 1982, a slight increase of the Bactrian camel population has been registered since 2010 (Fig. 6).

In India, several factors explain such decline: (i) the progressive mechanization of agriculture led to the progressive relegation of camels as draught animal in the "camel States" of the country (Rajasthan, Uttar Pradesh, Haryana and Gujarat); (ii) the declining use of camels for transportation work due to the increasing road construction in the northern States; (iii) the increasing role of synthetic fertilizers in local agriculture rather than camel manure; and (iv) the decreasing availability of land for camel grazing, especially since the implementation of irrigated plots following the Indira Gandhi canal implementation. However, if those factors can explain the slight decline up to 2009, the fall of camel population after 2010 is linked to political decision-making of the Indian government dominated by the BJP (Bharatiya Janata Party) which has declared camel (notably in Rajasthan, the most important camel State in India) as the "State animal", designating camels as similar to the IUCN (International Union for Conservation of Nature) Red List, i.e. critically endangered species (Meena 2018). Such protected status leads to the prohibition of slaughtering and to the control of migration and export. By this decision, selling and transporting camels outside of the State was banned, leading to the absence of markets and finally the abandonment of camel breeding. India had more than 900, 000 dromedary camel heads in 1961. The country declared only 311,000 heads only in 2018. 


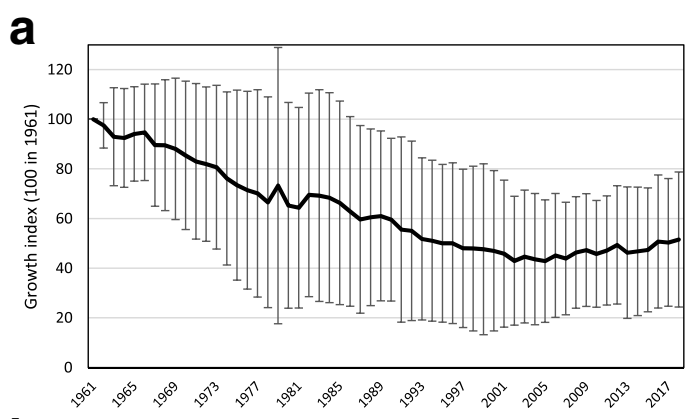

b

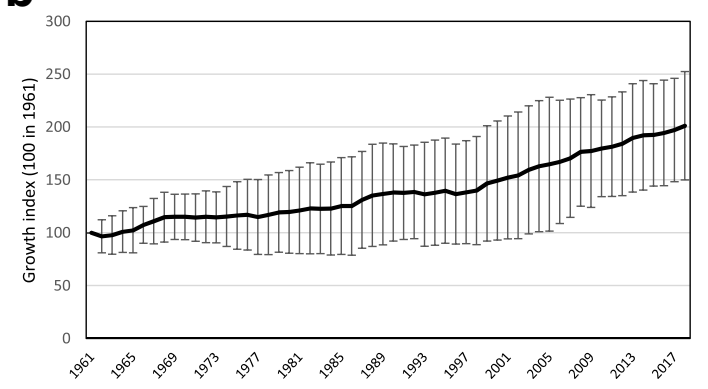

C
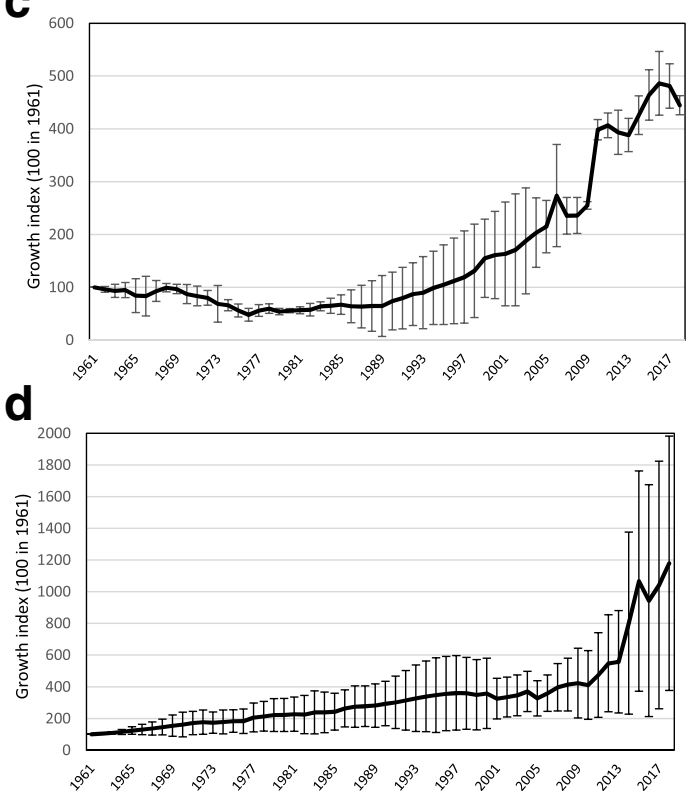

e

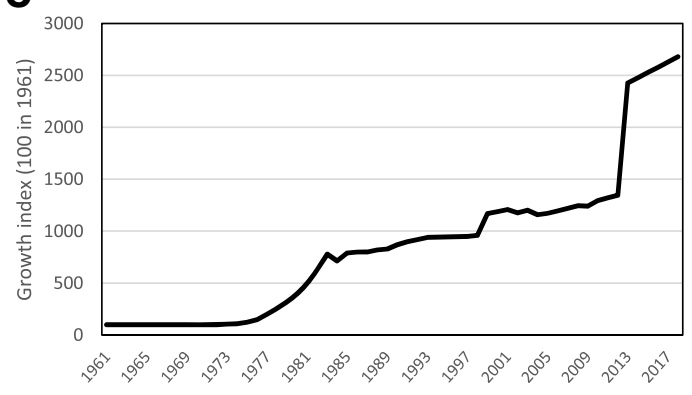

Fig. 1 Changes in camel demography from 1961 to 2018 according to different patterns. a Mean and standard deviation (SD) of camel population among camel countries with decline growth (type 1). b Mean and SD of camel population among camel countries with slight regular increase (type 2). c Mean and SD of camel population in Syria and UAE with decline followed by important growth (type 3). d Mean and SD of camel population with a sharp increase since 2010s after regular growth (type 4). e Change in camel population at Sultanate of Oman

Such a scenario is unique in the camel world, and the population pattern in China is quite different. Indeed, if similar factors were explaining the decline of Bactrian camel population in China since 1982 (mechanization of agriculture and transport after the economic openness policy starting in 1979), the change in the declining trend after 2010 could be linked to two factors: (i) the high added value of processed Bactrian camel wool on the international market (Faye 2015) and (ii) the growing interest of Chinese people in camel milk due to its expected medicinal virtues (Wang et al. 2018; Al-Haj 2020).

Another example is Turkey where the decline of camel population is the more important: from 65,390 heads in 1961, the official number of camels was only 1703 in 2018 , i.e. a decline of $98 \%$. Although the number of camels is probably higher, approximately 4000 according to nonofficial statistics (Caliskan 2016), Turkey is the only country in the world where the camel population has declined so drastically. However, this decline seems to have ceased for the last 10 years, and even a slight increase was recorded (Fig. 7). Indeed, since 2006, when the camel population was at its lower level (around 800 heads), the number of camels doubled. The reason underpinning the decline was linked also to the mechanization of transport and agricultural activities. Maintaining the residual camel population was linked to their specific use for camel wrestling which is culturally important in Turkey (Yilmaz and Ertugrul 2014; Ertürk 2019). Camel wrestling festivals, which are regularly organized in winter (i.e. during the rutting season), involve male hybrids (mainly crossbreed female dromedary $\times$ male Bactrian) produced locally or imported from Iran (Fig. 8). The part of the camel population devoted to milk production (mainly dromedary) is quite marginal but is increasing slightly. A current European project (acronym CAMELMILK) is supporting the development of a new camel dairy sector in the country (https://camel-milk.org). The diversification in camel use is the key to reverse the declining trend.

\section{Significance of the sharp increases in patterns 4 and 5}

The countries with "explosive" expansions of camel population (annual growth over 10\%) do not show a 
Table 2 Distribution (number of camel heads and percentage of the world camel population)

\begin{tabular}{|c|c|c|c|c|}
\hline \multirow[t]{2}{*}{ Patterns } & \multicolumn{2}{|c|}{ Number of camels } & \multicolumn{2}{|c|}{$\%$ camel population } \\
\hline & 1961 & 2018 & 1961 & 2018 \\
\hline Type 1: Negative growth & $3,647,892$ & $1,795,942$ & 28.21 & 5.11 \\
\hline Type 2: Slight regular increase & $7,874,046$ & $17,585,475$ & 60.89 & 50.01 \\
\hline Type 3: Rapid growth after decline & 113,000 & 513,666 & 0.87 & 1.46 \\
\hline Type 4: Sharp increase & $1,285,900$ & $15,004,200$ & 9.94 & 42.67 \\
\hline Type 5: Sudden increase (Oman) & 10,000 & 268,127 & 0.08 & 0.76 \\
\hline Total & $12,930,838$ & $35,167,410$ & 100 & 100 \\
\hline
\end{tabular}

regular growth for all the period spanning 1961-2018. In some cases, a sudden rise has occurred recently. For example, in Chad, the population suddenly increased from $1,550,000$ heads in 2014 to $6,413,000$ in 2015 , i.e. multiplied fourfold. In Kenya, the camel population was more than twice in 2012 (3,065,400 heads) compared to 2011 (1,350,000 heads). In Nigeria, the ratio between the camel population in 2013 and in 2012 was 14:1 (285,000 vs 20,500). Less important but still surprising, strong spikes occurred in Saudi Arabia (in 2015), in Qatar (in 2011) and in Oman (in 2013).

In Chad, this spectacular change was linked to the official census of the national livestock achieved in 2014 . Due to this unexpected change in the camel population, FAO has recently modified its former estimations (Fig. 9). However, such modification does not change the mean annual growth for the period 19612018 (43.7\%) which cannot be explained by a natural

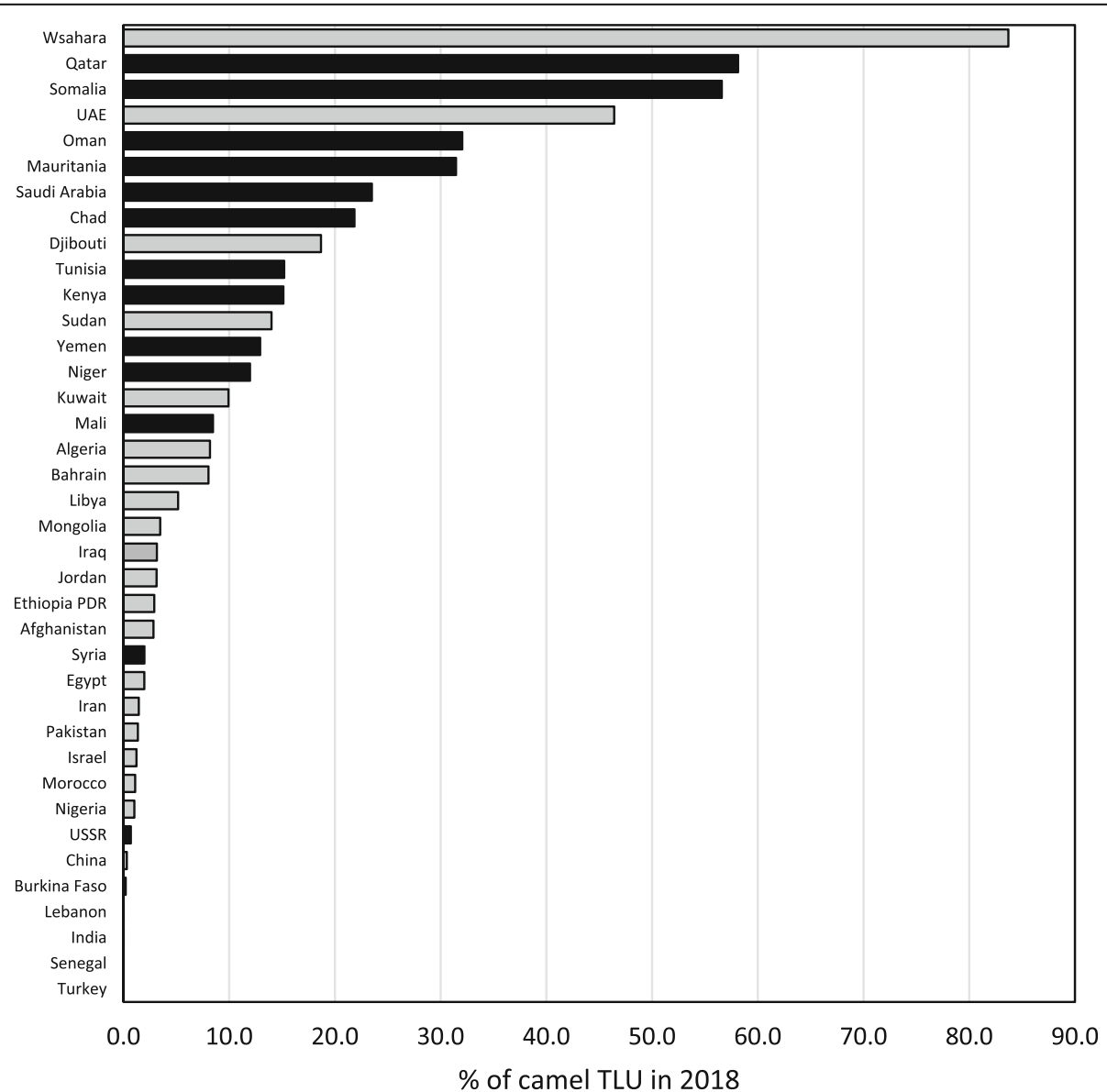

Fig. 2 Percentage of camel stock in the total TLU in camel countries in 2018. In grey, the countries with decreasing percentage since 1961. In black, the countries with increasing percentage since 1961 


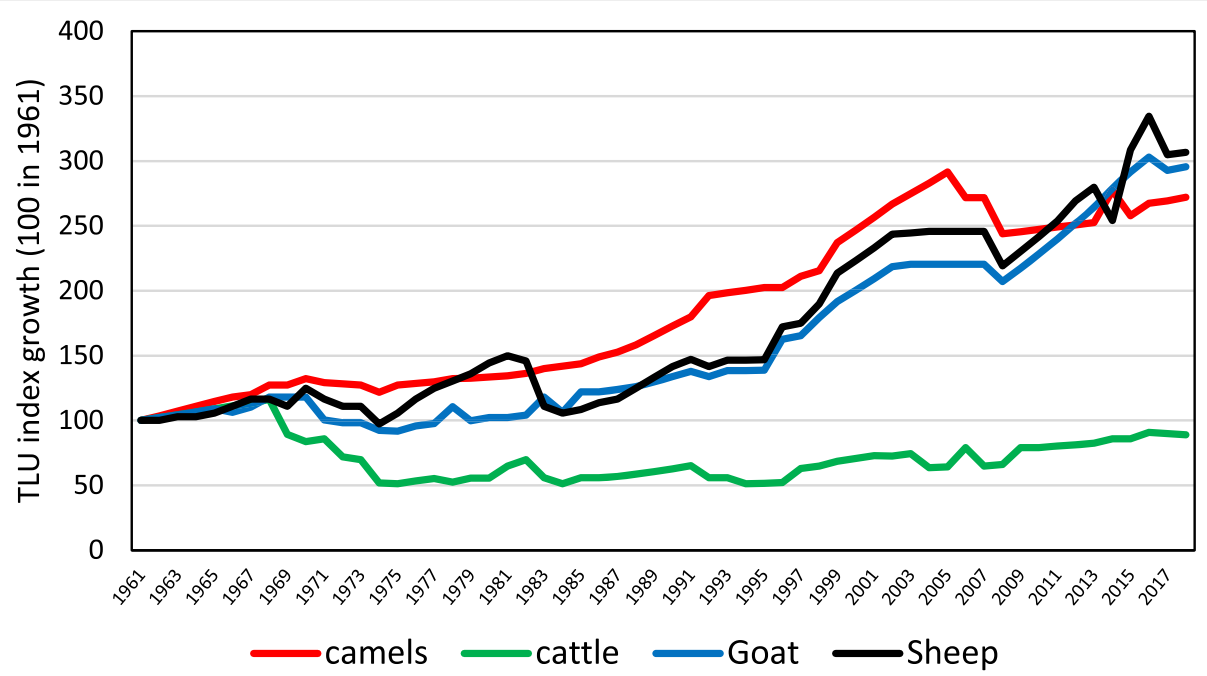

Fig. 3 Change of tropical livestock unit (TLU) index for different farm species in Mauritania between 1961 and 2018 (source FAOstat)

growth of the population, especially since Chad is not an importing country.

In Kenya, a census was also performed in 2011. The readjustment of data by FAO has only modified the date of the rise in camel population which appears for the moment between 2006 (1,057,900 heads) and 2007 (3,156,492 heads), i.e. multiplied threefold (Fig. 10). A similar figure is observed in Nigeria where the spectacular rise observed in 2013 was moved after readjustment in the year 1998.

The sudden increase in camel populations could be also related to massive import of live animals. The Arabian Peninsula countries are among the main camel importing countries (Faye 2013). However, the official import-export balance of camels could only partly explain the sudden change in population pattern, for example in Saudi Arabia (Fig. 11a). Indeed, the main purpose of importing camels is for slaughter after 3-6 months fattening in feedlots (Faye et al. 2013a). So, imported animals are weakly responsible for the increase in the local camel population (Fig. 12).

However, the pattern of official camel trade in Oman is different. At the time of the sudden increase of the camel population in 2013, the import-export balance was negative: between 2012 and 2017, more than 210, 000 camels were exported while only 5187 camel heads were imported. In Qatar, as well as Saudi Arabia, the import-export balance has been positive and, at least for

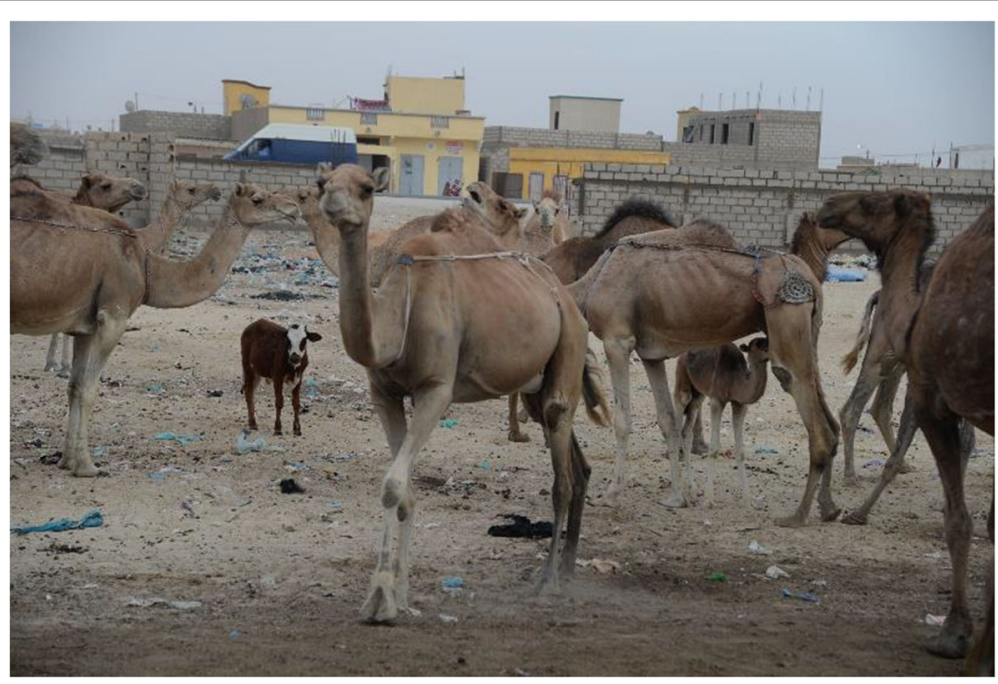

Fig. 4 Dairy camel farm in peri-urban area of Nouakchott, Mauritania (Ph. B. Faye) 


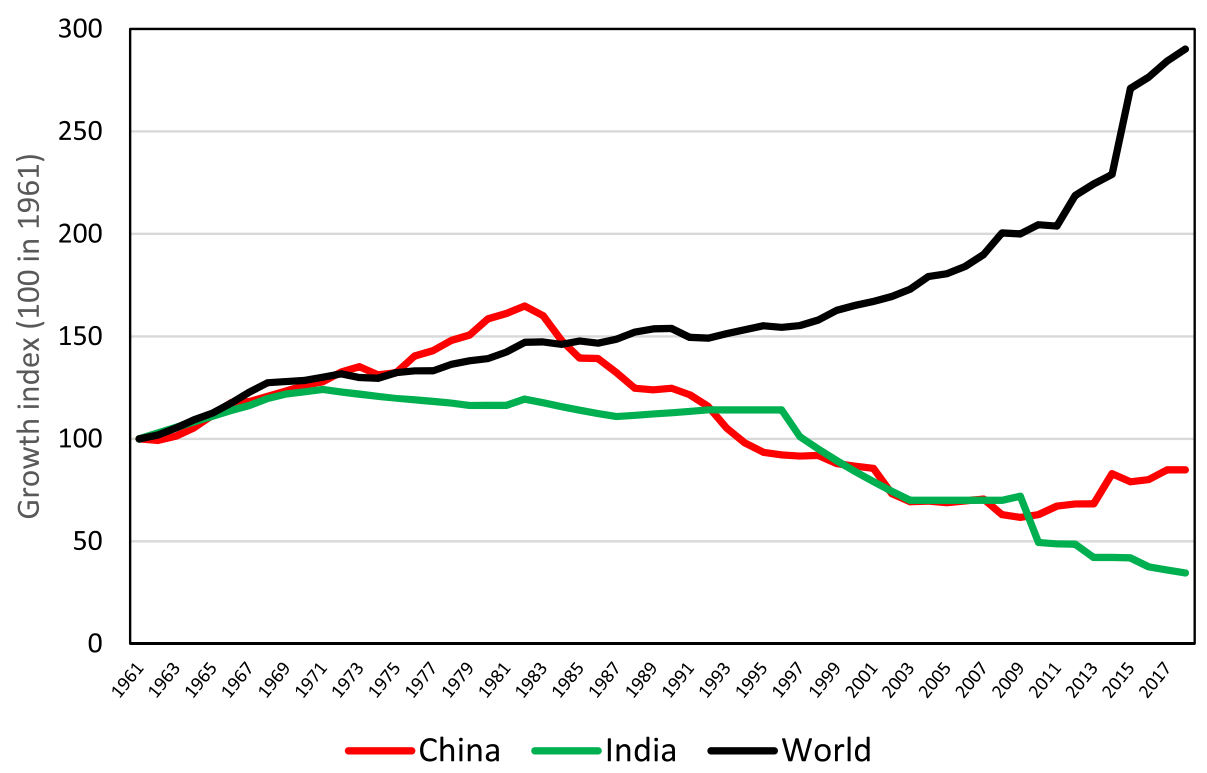

Fig. 5 Camel demographic change 1961-2018 in the world, in India and China

the last 10 years, could explain the important increase in the camel population (Fig. 11b).

\section{The missing information}

Camel distribution in the world should be wider than what is posted on the FAOSTAT website. Camels are present in more than the 46 national entities listed in 2018. The main country that is lacking is Australia where camels were introduced in the nineteenth century (Jones and Kenny 2010). Certainly, most of the
Australian camels are wild, and this explains the lack of declaration because FAO is recording only domestic animals. However, a part of this camel herd is valorized on national or international markets for meat production (Fig. 13), for live animals' export or even for milk production (Zeng and McGregor 2008). Moreover, the accurate number of camel heads in the country is still subject to debate. Using different procedures to calculate camel density in the central desert of the country, Saalfeld and Edwards (2010) estimated the number of camels

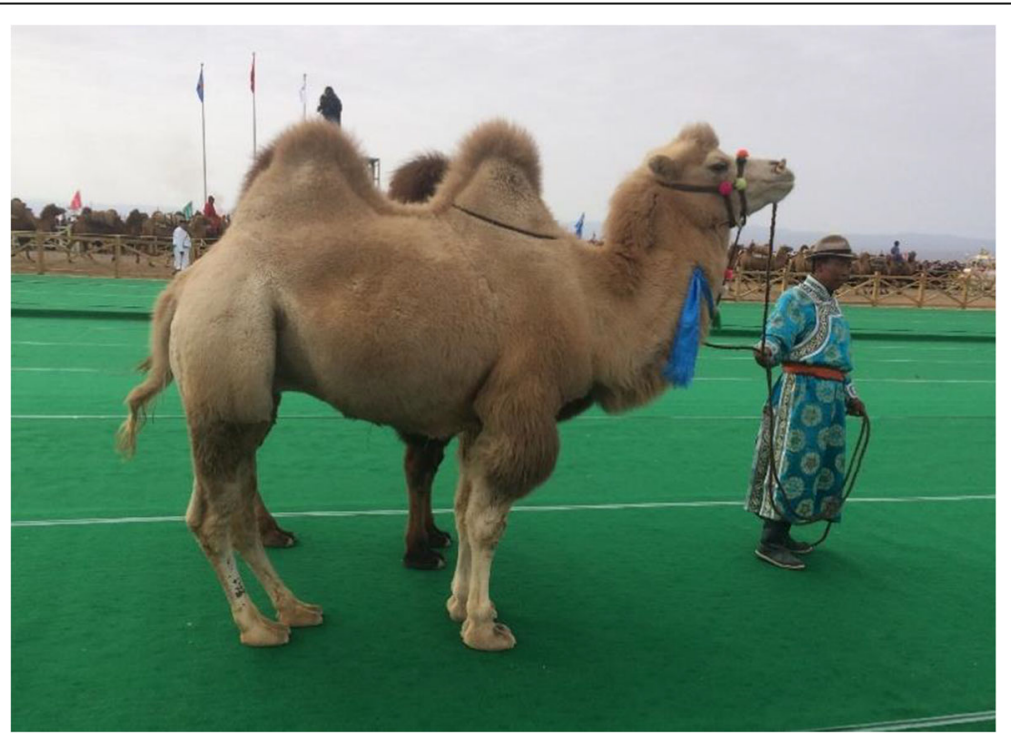

Fig. 6 Bactrian camel at Al-Ashan desert festival, Inner Mongolia, China (Ph. B. Faye) 


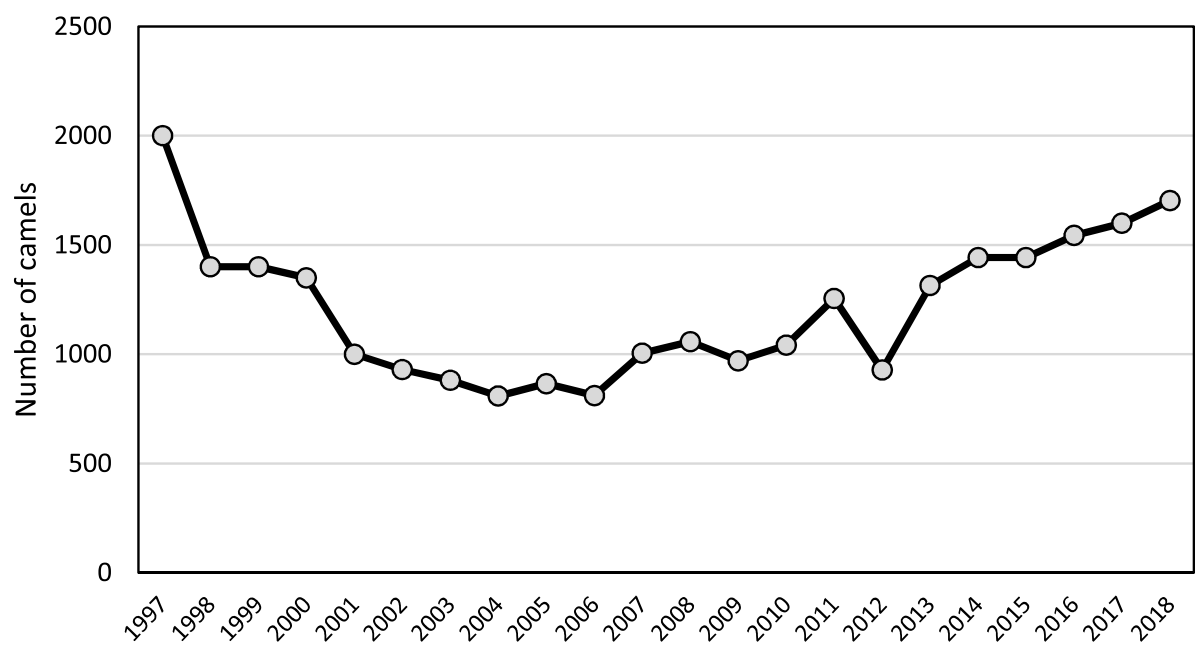

Fig. 7 Changes in Turkish camel population for the last 20 years (source: FAOstat)

was between 953,000 and 2,000,000 heads. Later, those numbers were considered as overestimated (Lethbridge et al. 2016). A more realistic estimation of 400,000 wild Australian camels was proposed by scientists from Queensland University (Al-Jassim and Lisle 2016).

If Australia has the most important camel population missing in the international FAO database, other countries with a significant number of camels are also missing. For example, Spain is the only European country having a native camel population. This population, though not indigenous, was mainly introduced in the Canary Islands since the fourteenth century (Wilson and Gutierrez 2015). The present population is around 1200 heads (but according to people, different figures between 800 and 2000 were put forth). Strategically, the camel herd in the Canary Islands is important, as it is the only source of camels able to be imported in other European countries, the sanitary regulations being a barrier for introduction from other camel countries. The initial use of those animals was previously restricted to agriculture and transport activities. Nowadays, they are used in the tourism sector (Schultz 2008). The diversification of camel production enthusiastically promoted by local authorities has never been borne out. Milk production remains incidental (Diaz-Medina 2017), and meat production not yet possible due to the lack of regulations.

\section{The new "camel countries"}

Two kinds of new camel countries can be described: (i) the countries of recent establishment where camels are contributing to the diversification of livestock industry, mainly in Western countries, and (ii) the countries newly

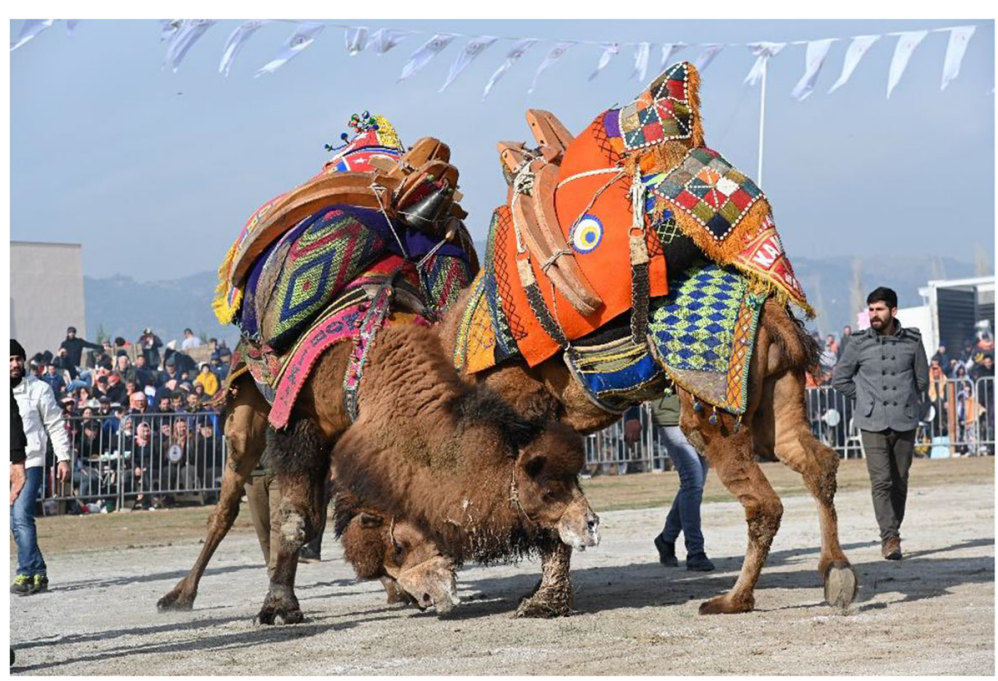

Fig. 8 Camel hybrid at camel wrestling festival, Inçirliova, Turkey (Ph. B. Faye) 


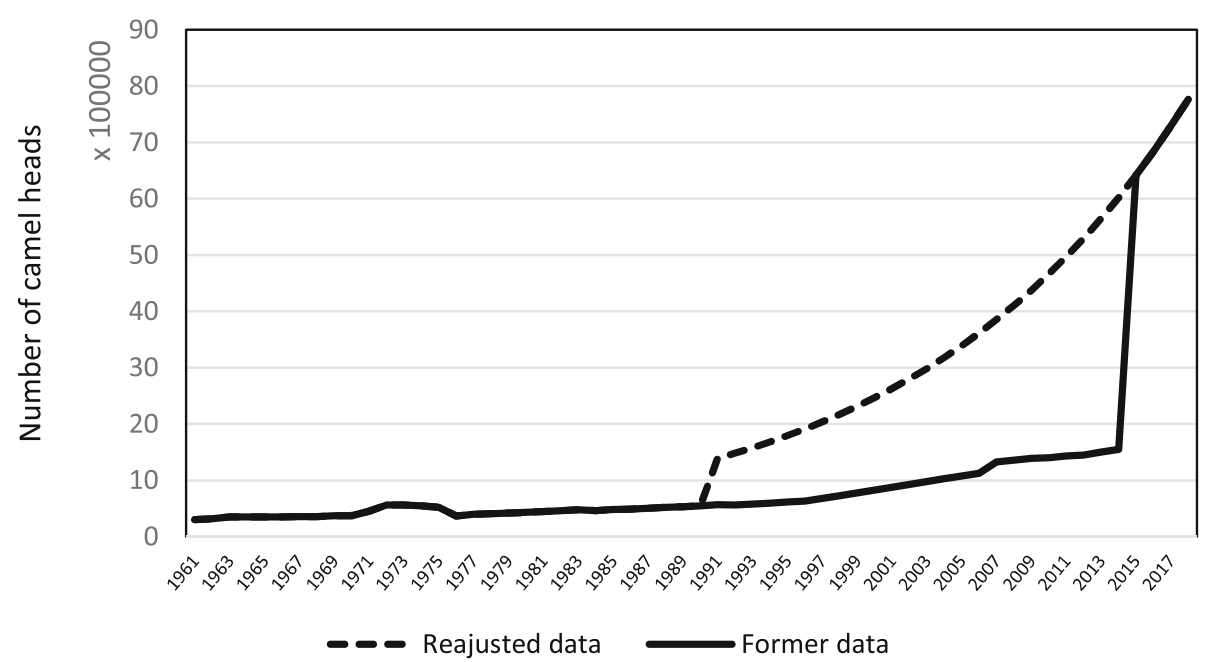

Fig. 9 Demographic changes of camel population in Chad 1961-2018 before and after readjustment following the camel census occurring in 2014

occupied by camel farming following the expansion of the former camel distribution area, mainly in Africa.

\section{New camel implementation in Western countries}

In Europe, the presence of camels was common across the Roman Empire where camels were used for transportation all along the Roman ways up to the northern part of the Empire, in France, Belgium, Germany and even England (Henrotay and Pigière 2012). Iconographic, written and osteological evidence of this presence involved both dromedaries and Bactrian camels as well as hybrids (Tomczyk 2016). The use of camels was also regularly mentioned in the Middle Ages, in Spain, France or Italy (Dioli 2015), but almost disappeared for good later. In the twentieth century, except in the Canary Islands as mentioned above, camels were mainly confined to zoological gardens and circuses (Faye and Brey 2005). However, for the last 25 years, new camel farms have been established in Western Europe, mainly as tourism attractions (Faye et al. 1995) and more recently for milk production, for instance Smits Farm in The Netherlands (Smits and Montety 2009). Unfortunately, the number of camels in Europe is not registered, but can be estimated at around 5000-6000 heads all included. A European Camel Federation is under creation. The development of camel farming in Europe is contributing to sustainable diversification of livestock production as well as for local touristic activities. The number of camels in

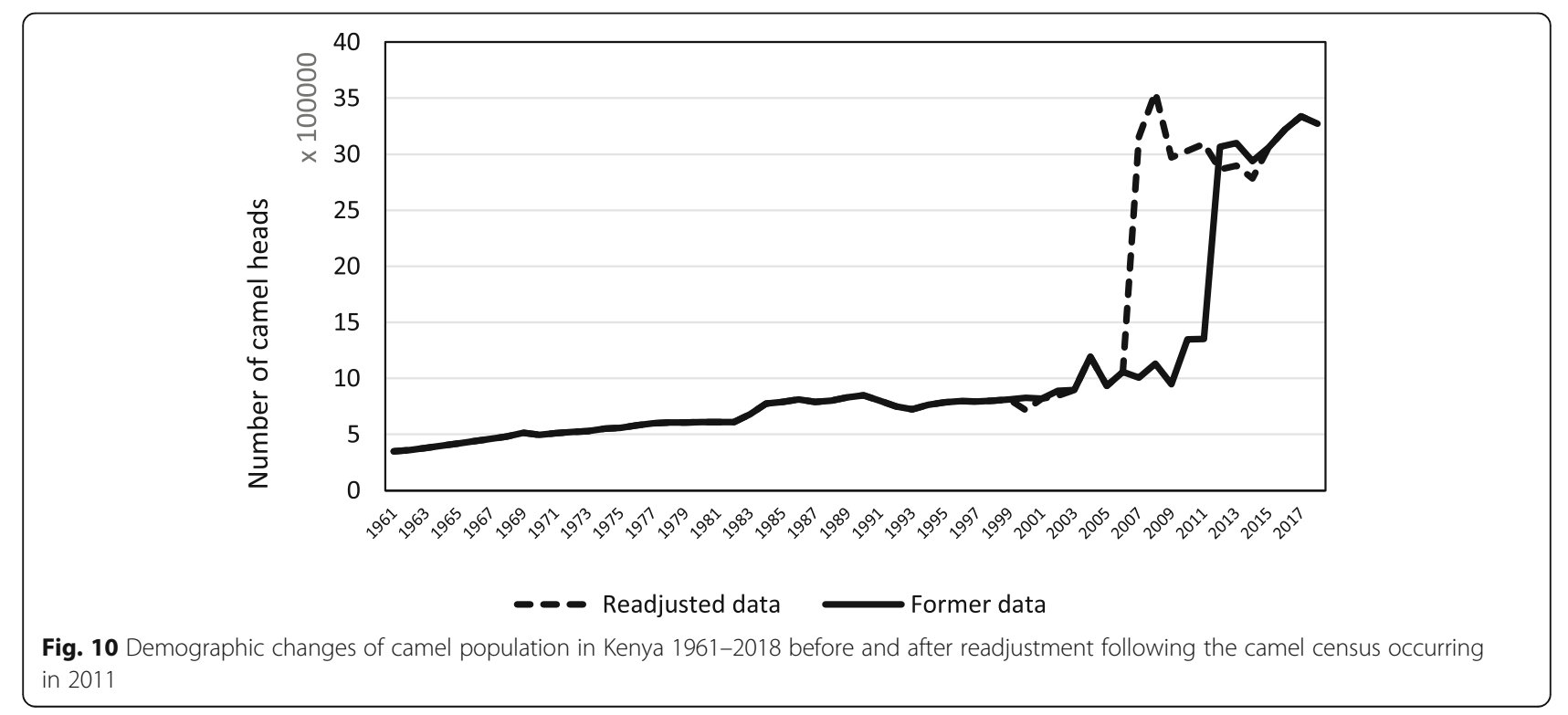


a

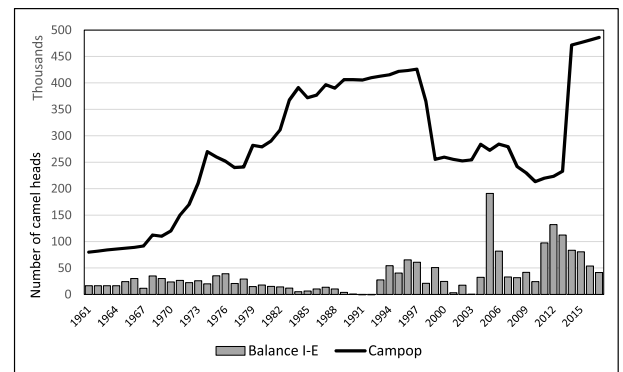

b

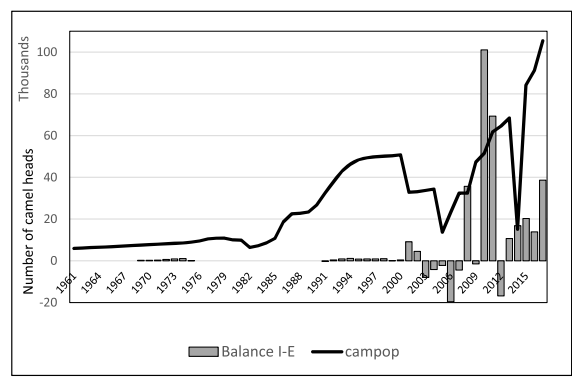

Fig. 11 Camel demographic pattern in Saudi-Arabia (a) and Qatar (b) for the period 1961-2018 and balance of import-export live camels

European countries is certainly marginal but can be higher than "official camel countries" like Lebanon or most of the Central Asian Republics. For example, in France, the camel population is estimated between 1000 and 1500 heads, i.e. a comparable number to that of Bahrain (Fig. 14).

In the USA, a trend similar to Western Europe is observed. With the support of President Jefferson Davis in the middle of the nineteenth century, for the US army based in arid areas of the country, 75 dromedary camels were imported from North Africa and put to work packing military supplies. Camel caravans were a common activity between San Antonio and Los Angeles just prior to the civil war from 1861. At the same time, commercial shipments totalling as many as 400 camels were imported in Texas, Alabama and California, but they were gradually replaced by horses (Young 1982). Nowadays, the number of camels in the USA is estimated to roughly amount to 3000 heads distributed mainly in private farms as touristic attractions, but also for dairy production (https:// desertfarms.com/). One of the reasons for camel dairy farming development is the belief that camel milk could have a beneficial impact on autistic children and diabetic patients (Adams 2019).

\section{New implementations in Southern countries}

The establishment of commercial or tourism-oriented camel farms is not limited to Western countries. Many introductions have occurred for example in the African safari parks in the southern part of the continent, but also in commercial farms. If in Namibia a small camel herd (less than 100 animals) has been registered in the FAO database since 2013, their presence in this arid country has been attested since 1889, brought from the Canary Islands by German troops (Wilson 2012). In the neighbouring country of Botswana, the Tsabong Camel Park (TCP) in the southern part close to the South African border has a larger camel herd of 370 heads used for tourism (Seifu et al. 2019). In the other countries of the region (South Africa, Zimbabwe, Zambia, Lesotho,

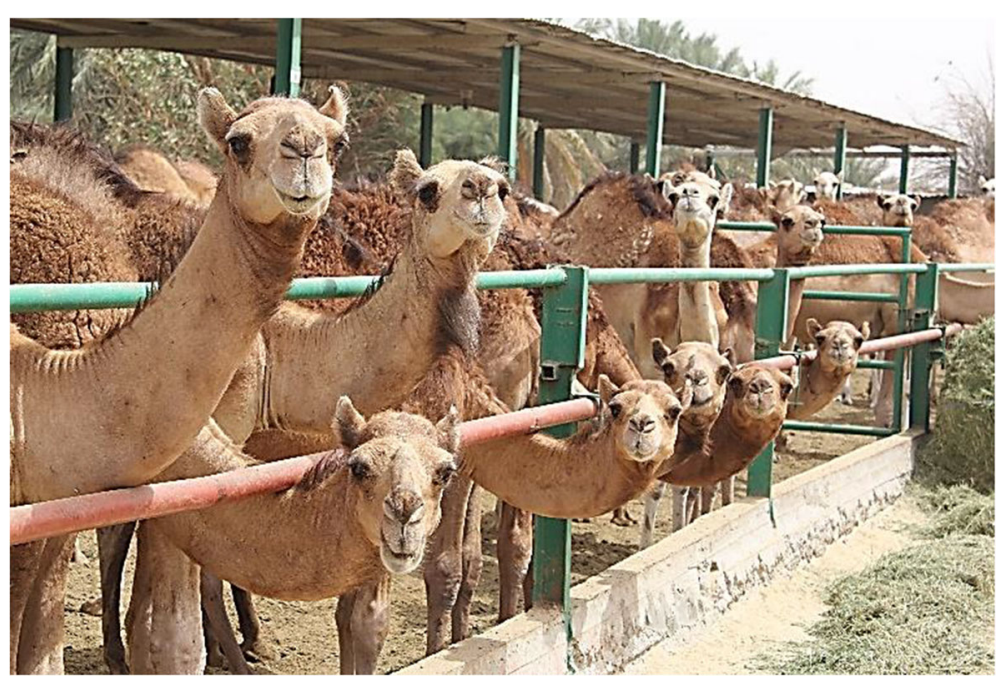

Fig. 12 Camel fattening farm, Kharj, Saudi Arabia (Ph. B. Faye) 


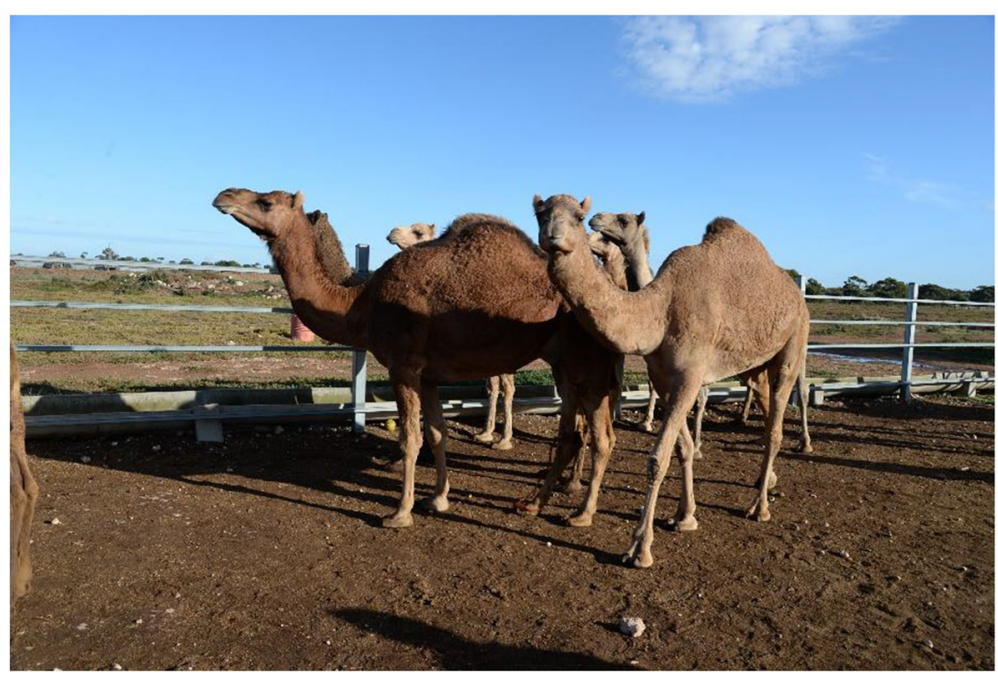

Fig. 13 Camel farm for meat and milk production, region of Adelaide, Australia (Ph. B. Faye)

Swaziland, Malawi, Mozambique), dromedary camels were introduced by Europeans during the colonial period in the late nineteenth and early twentieth centuries for military and police activities or postal services. Few of those camels survived except in South Africa, but new introductions occurred in the late twentieth century through gifts from the former president Ghaddafi of Libya to the heads of these states (Wilson 2013). Nowadays, the camel population in those countries is incidental, except in Tanzania where some Maasai pastoralists, traditionally cattle breeders, began to use camels in their villages (Swai et al. 2011a). No census is available, but in 2006, the estimation of Tanzanian Ministry of Livestock was 93 animals (Wilson 2011). Later, in their survey on camel diseases observed in Tanzania, Swai et al. (2011b) included 193 camels.

New camel introductions were also observed in Asia. The most surprising is the establishment of one camel dairy farm in Bangladesh with 45 camels (Wilson 2019) where several studies were reported (Islam et al. 2016; Fazal et al. 2017).

\section{The expansion of camel farming in the Sahara margins}

For the past 30 years, expansion of the camel distribution area, linked to the droughts as mentioned above, can be observed in the southern part of the Sahara and Sahel. This expansion included first the southern part of Sahelian countries of Mali, Niger or Chad (Faye et al. 2012), usually cattle farming areas. For example, in Chad, camel herds usually bred according to long transhumance patterns go to the border of the Republique Central Africaine or even beyond (Marty et al. 2009). In Niger, camel population growth was higher in the departments of Maradi,
Zinder or Diffa located in the southern part of the country than in the Saharan departments (Faye et al. 2013b). In Ethiopia, the expansion of camel population was illustrated by the increased altitude limit at which camels were usually living, going from $1500 \mathrm{~m}$ in the 1980 s up to $2000 \mathrm{~m}$ today (Tefera and Abebe 2012).

But camel farming is also expanding in the countries formerly associated with the "Sudanese" climate of 500$800 \mathrm{~mm}$ annual rainfall. Camel breeding is currently observed in the north of Nigeria, Cameroon, Republique Central Africaine, Uganda and even Tanzania as already mentioned, although only Nigeria among these countries has a declared camel population in the FAO database. In Uganda, for example, where camel production is contributing to overall resilience to droughts (Asiimwe et al. 2020), the camel population in 2017 was as high as or more than 40,000 heads (Wilson 2017).

\section{Official data or estimation?}

Official data registered in the FAO database are provided by the various national statistics offices of the Ministries of Agriculture or Livestock in these countries. However, in many cases, those data are not supported by an accurate census of the camel stock. Generally, for estimation from a starting data point, a growth percentage is applied systematically which could be readjusted later if a census is achieved as mentioned above in the case of Chad. For example, in Mauritania, the same annual growth (3.6\%) was observed between 1962 and 1967 and later an annual growth of $1.7 \%$ was applied every year from 2009 to 2013. The same growth of $3.6 \%$ was applied regularly in Nigeria. Camels, unlike cattle, are not submitted to 


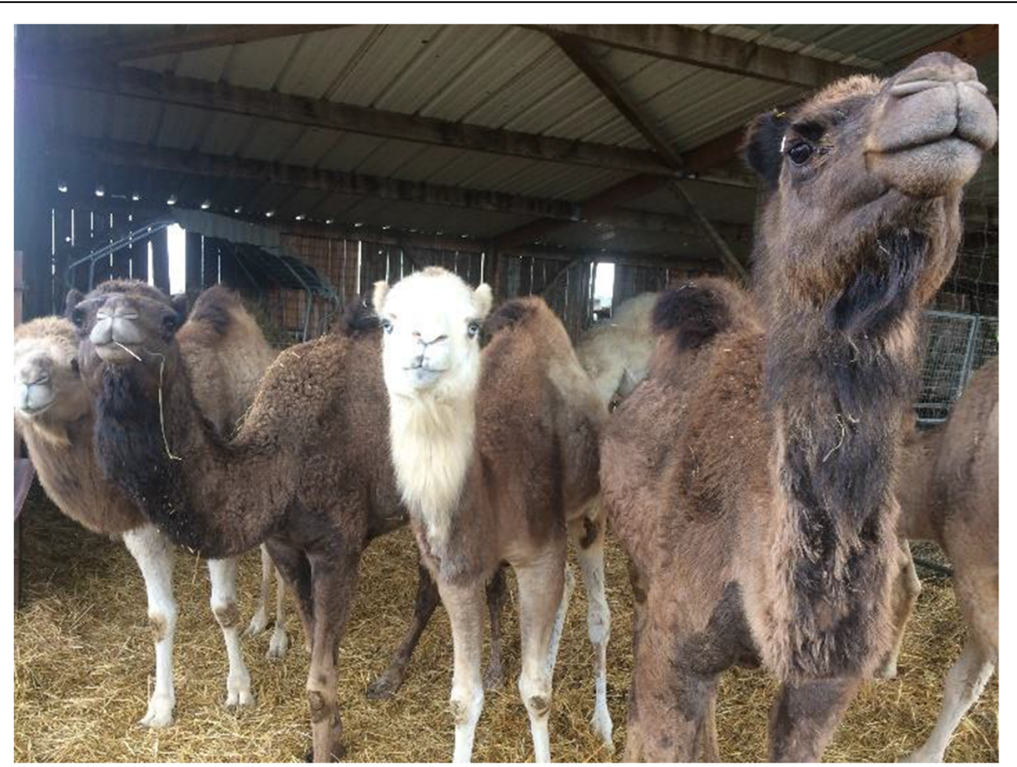

Fig. 14 Camel farm for tourism attraction, Feignies, France (Ph. B. Faye)

mandatory vaccination campaigns. Therefore, censuses are rare, and most of the countries cannot achieve them due to their incurred cost. So, in most of the cases, official figures are rough estimates at most.

Another difficulty is the transboundary movements and mobility of camel herds which are not welldocumented (Faye 2019). For example, in Algeria, the camel population has slowly declined after independence and then suddenly increased in 1999. Such a change was associated with the launching of the National Fund of Agricultural Development (FNDA) during that year and including the provision of subsidies for newborn camels and carrying out a camel herd census. Therefore, Algerian camel breeders redirected their camels grazing beyond the border, in Niger (Faye et al. 2014). The border closure between Saudi Arabia and Qatar in 2018 also led to an important transborder movement of camel herds from Saudi grazing areas to Qatar as mentioned in the press (https://gulfbusiness.com/qataris-ship-home-thousands-camels-stranded-saudi-via-kuwait/).

Sometimes, an important gap is observed between official data collected in FAO database and those provided by some national authorities. For example, in Saudi Arabia, Elzaki Ali et al. (2018) noted that, based

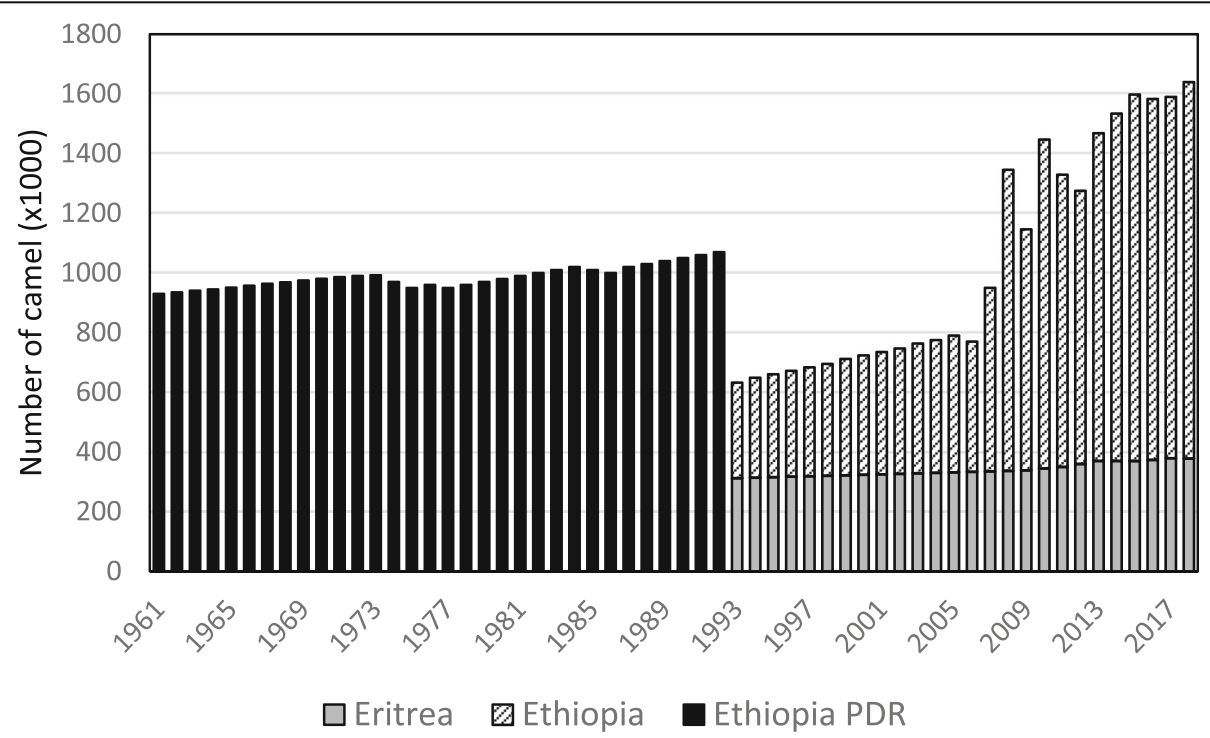

Fig. 15 Changes in camel stock in Ethiopia PDR (1961-1992) and in the sum Ethiopia + Eritrea (1993-2018) according to the FAOstat data 


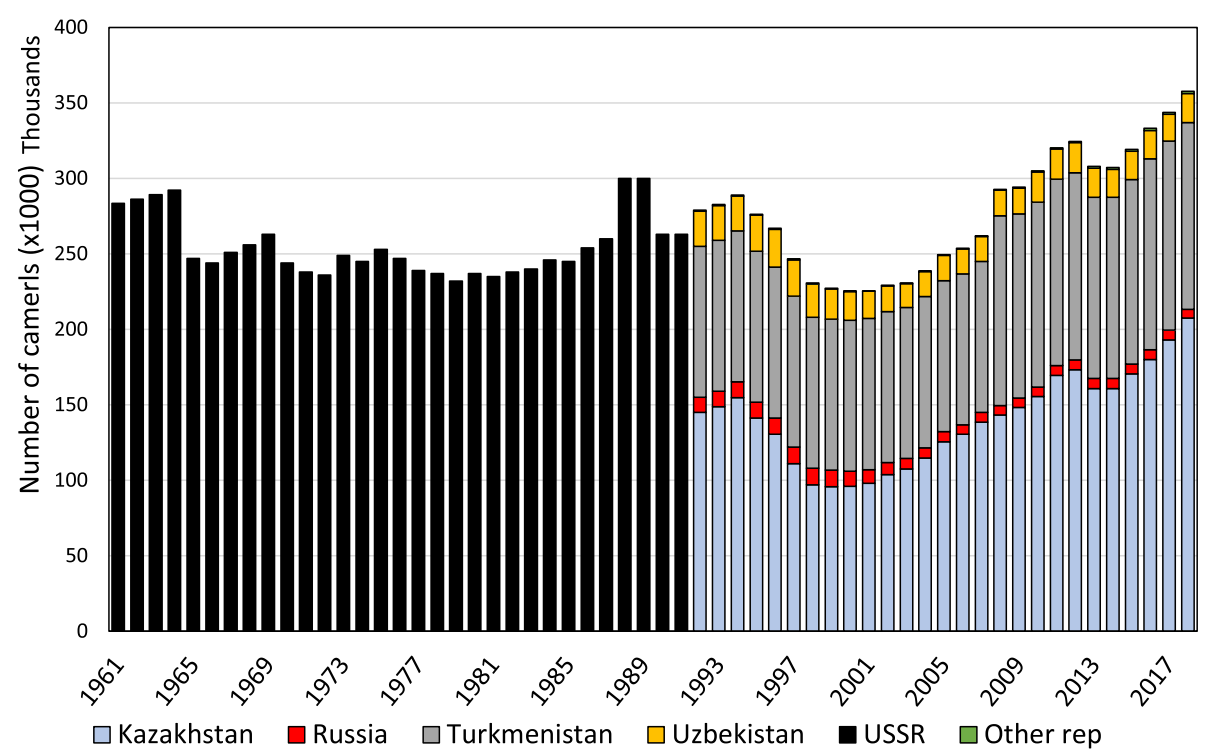

Fig. 16 Changes in camel stock in USSR (1961-1991) and in the sum of new independent states (1992-2018) according to the FAOstat data

on the data of General Statistics Authority (GSA), the camel population decreased from 301,717 heads in 2015 to 248,205 heads in 2016 while for the same years in the FAOSTAT website the numbers were 476,398 and 481,138 camel heads, respectively. In contrast, for Al-Ahmadi et al. (2019), based on the data edited by the Ministry of Environment, Water, and Agriculture in Saudi Arabia, the number of camels is estimated at more than 1.39 million heads in 2018 and has been growing annually by $5.2 \%$ since 1961 . According to FAOSTAT (2020), the values are 490,672 heads and $9.01 \%$ annual growth. Such information is repeated in the press where it is stated that "with 1.4 million camels in country, Saudi Arabia ranks third in the Arab world, behind Somalia and Sudan" (https://gulfnews.com/ world/gulf/saudi/saudi-arabia-pushes-for-internationalforum-on-camels-1.2007007).

In Ethiopia also, the number of camel heads in the country is subject to contradictory statements. For example, Mirkena et al. (2018), citing an IGAD (Inter-Governmental Authority for Development) working paper, stated that the camel population in Ethiopia is estimated at 4.8 million heads while according to FAOSTAT (2020), the camel stock is around 1.2 million. The gap holding between official FAO data and national sources has been observed for a considerable portion of time.

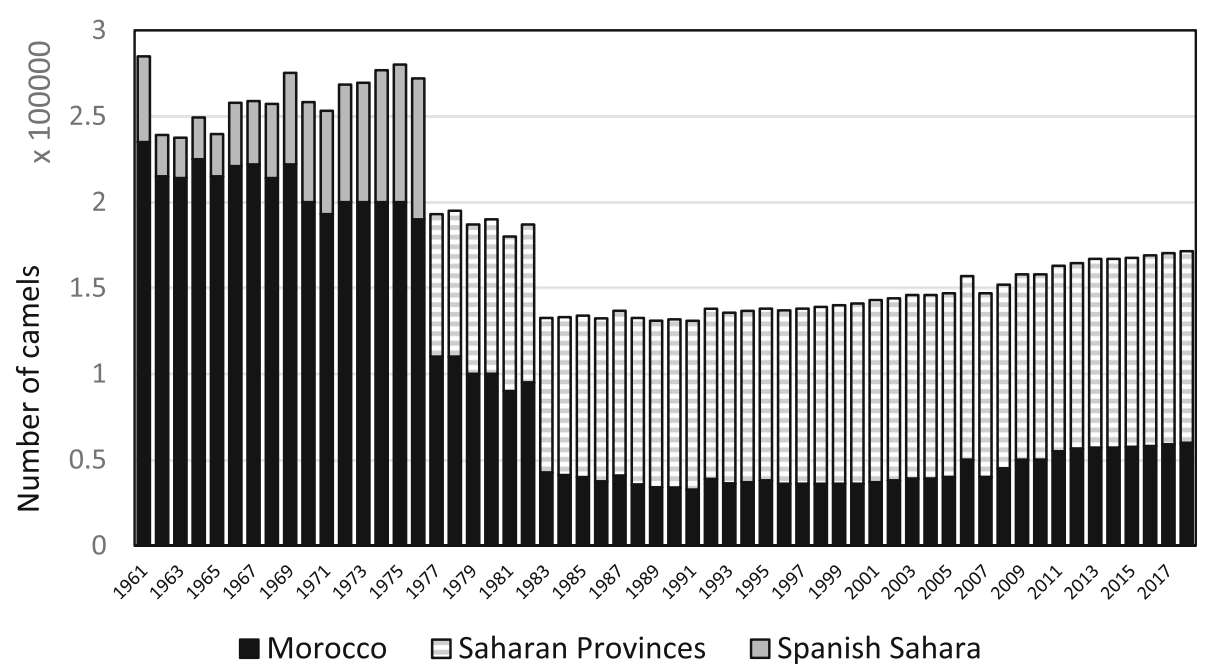

Fig. 17 Changes in camel stock in Morocco (1961-2018) and in Sahara during Spanish colonization (1961-1976) and after inclusion in Moroccan Kingdom as Saharan provinces (1977-2018) 


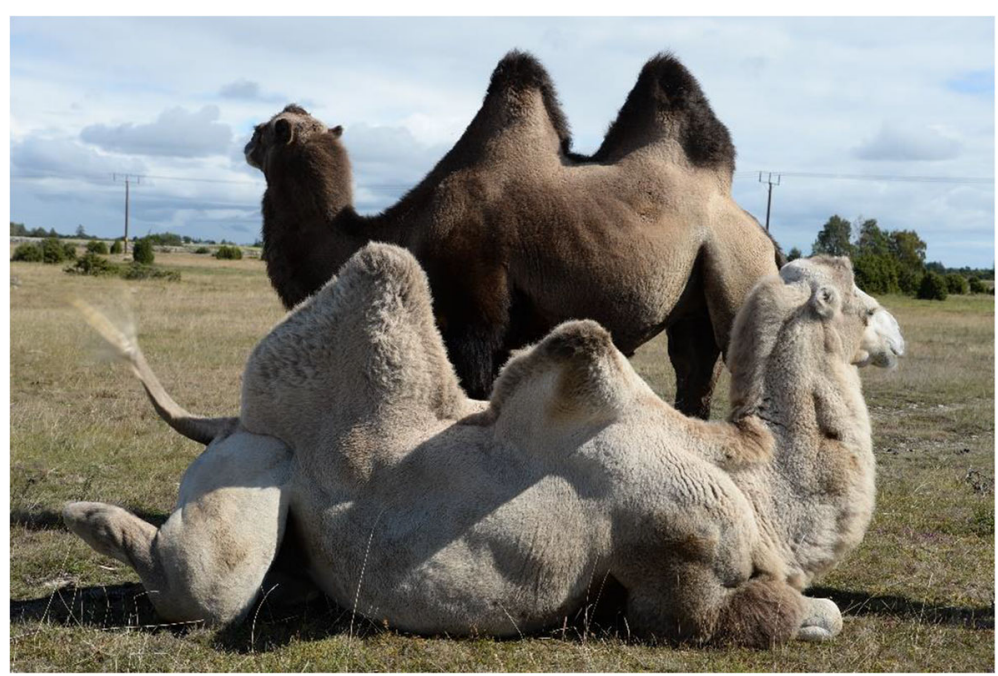

Fig. 18 Bactrian camel farm for tourism attraction, Öland island, Sweden (Ph. B. Faye)

Citing data from the Central Statistics Authority (CSA) in 2007, Kebede and Gelaye (2010) stated that the camel population in Ethiopia was 1.7 million heads while it was 615,000 heads in the FAO database. From their part, Asres and Yusuf (2014), citing FAO data, stated that "Ethiopia possesses over 2.4 million dromedary camels that stand the country third in Africa in camel population" while, in fact, only one million heads approximately are registered in the FAO database at that time.

\section{Consistency and inconsistency after secession or independence}

The merger of data from different countries formerly gathered in one unique national entity is a check on their consistency. The example of Ethiopia is once again interesting. After Eritrea seceded in 1992, Ethiopia PDR (People's Democratic Republic) was divided into Ethiopia and Eritrea. However, the sum of camel stocks declared in Eritrea added to the Ethiopian stocks did not correspond to the previously recorded number of heads (Fig. 15).

Subsequent to the collapse of the Soviet Union in 1991, new independant states (NIS) emerged. Among them, seven declared camel stock (mainly Bactrian) in FAO database. Those countries were Azerbaijan, Kazakhstan, Kyrgyzstan, Tajikistan, Turkmenistan, Uzbekistan and Ukraine in addition to Russia. Unlike in Ethiopia, the changes in camel stock appeared to be reasonably consistent (Fig. 16). The decline observed in the post-independence period is mainly

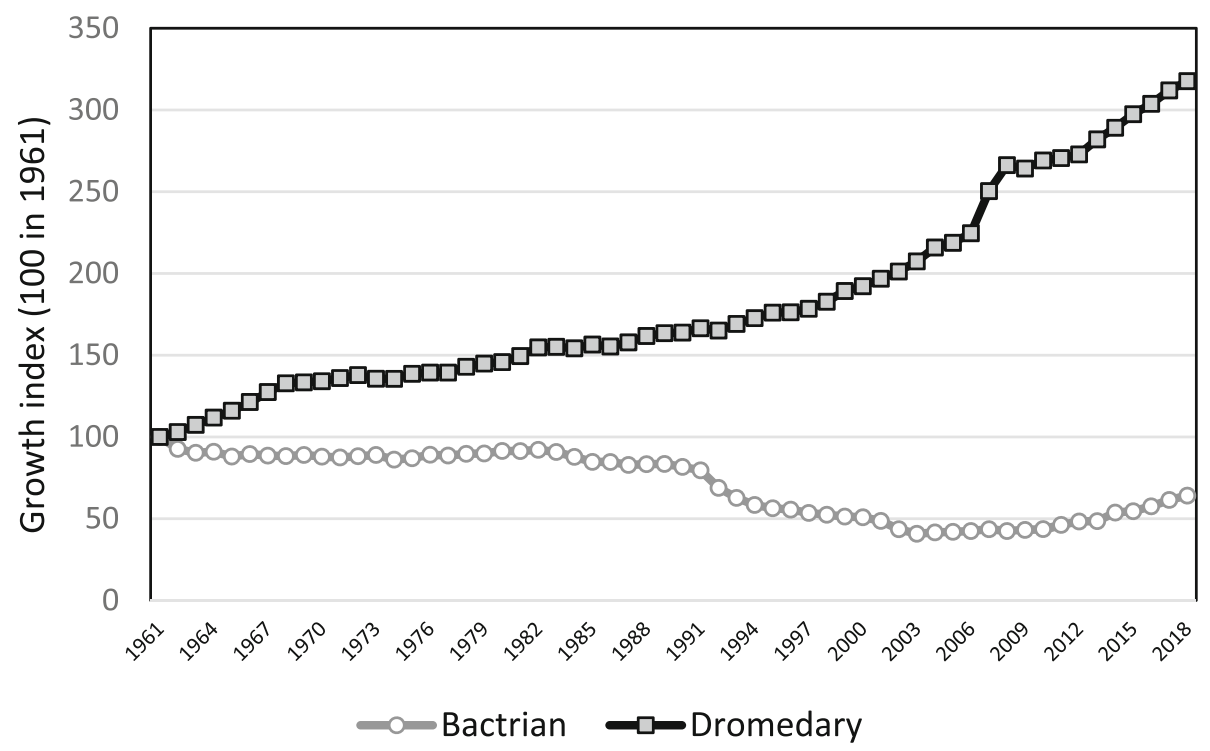

Fig. 19 Comparative demographic changes between Bactrian and dromedary camels at world level 1961-2018 (source: FAOstat 2020) 


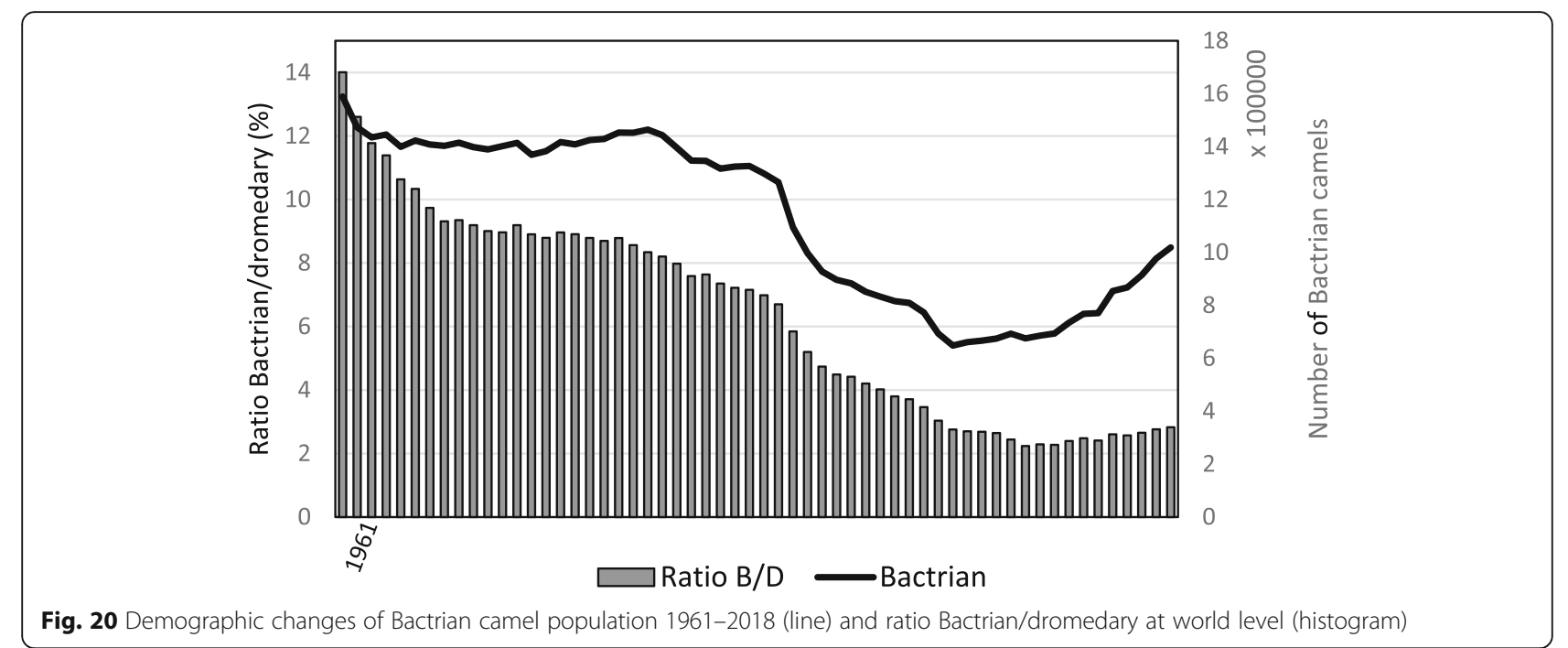

linked to the impact of the privatization process of agricultural farms, especially in Kazakhstan (Kerven et al. 2006).

In 1976, Morocco included the former Spanish Sahara into its national entity. Named "Western Sahara" in the official FAO database, the former Spanish Sahara was declared as "Saharan provinces" by the Moroccan government. Regarding the camel population, a sharp decline was observed from 1977, just after the "green walk", but this sudden decrease was essentially observed in the former Morocco and was not compensated by the Saharan camel stock, which increased slowly at the same time (Fig. 17).

\section{Dromedary vs Bactrian}

The FAOSTAT database did not allow distinguishing between the different species of large camelids. The data regarding camel herds include both dromedary and Bactrian. Some countries have only Bactrian camels, such as Mongolia, China and Russia, or Bactrian camels are significant proportions of their large camelids' population as shown in the case of the other Central Asian Republics. For example, in Kazakhstan, the number of Bactrian camels represents $85 \%$ of the total camel stock (Imamura et al. 2017). Bactrian camels are also present in Iran (NiasariNaslaji et al. 2009), Pakistan (Isani and Baloch 2000), India (Makhdoomi et al. 2013), Afghanistan (Tapper 2011), Turkey (Dioli 2020) and Ukraine (Burger et al. 2019). Some Bactrian camel farms overlap in Western countries, such as Austria or Sweden (Fig. 18). However, in all those countries, the number is marginal or even incidental (Zarrin et al. 2020).

Moreover, due to the common practice of crossbreeding (hybridization) between dromedary and Bactrian camels, notably in Kazakhstan, Iran and Turkey (Faye

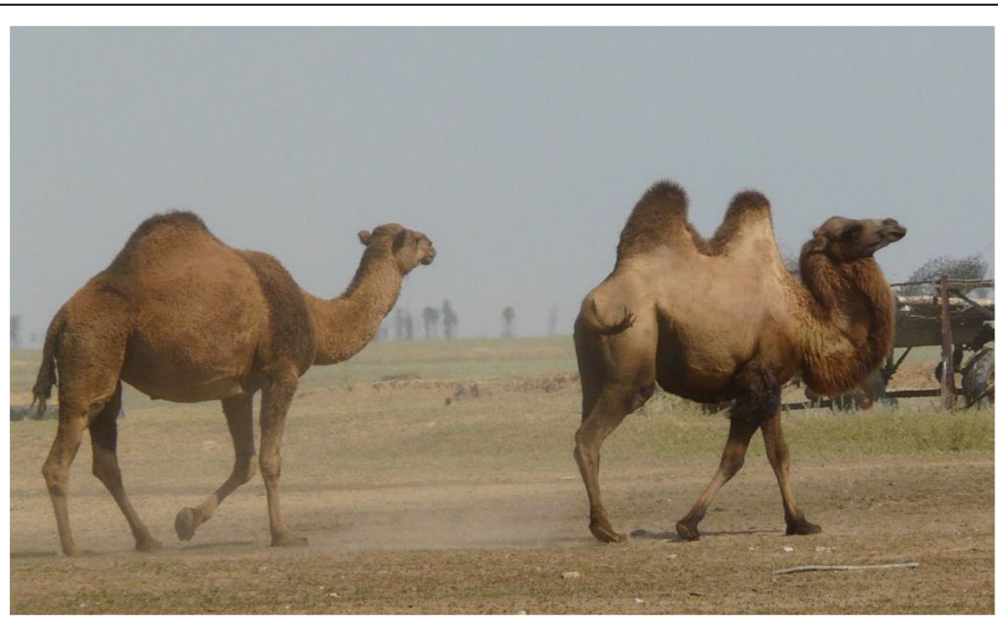

Fig. 21 Dromedary and Bactrian camels cohabiting in the same farm, Ouralsk, Kazakhstan (Ph. B. Faye) 


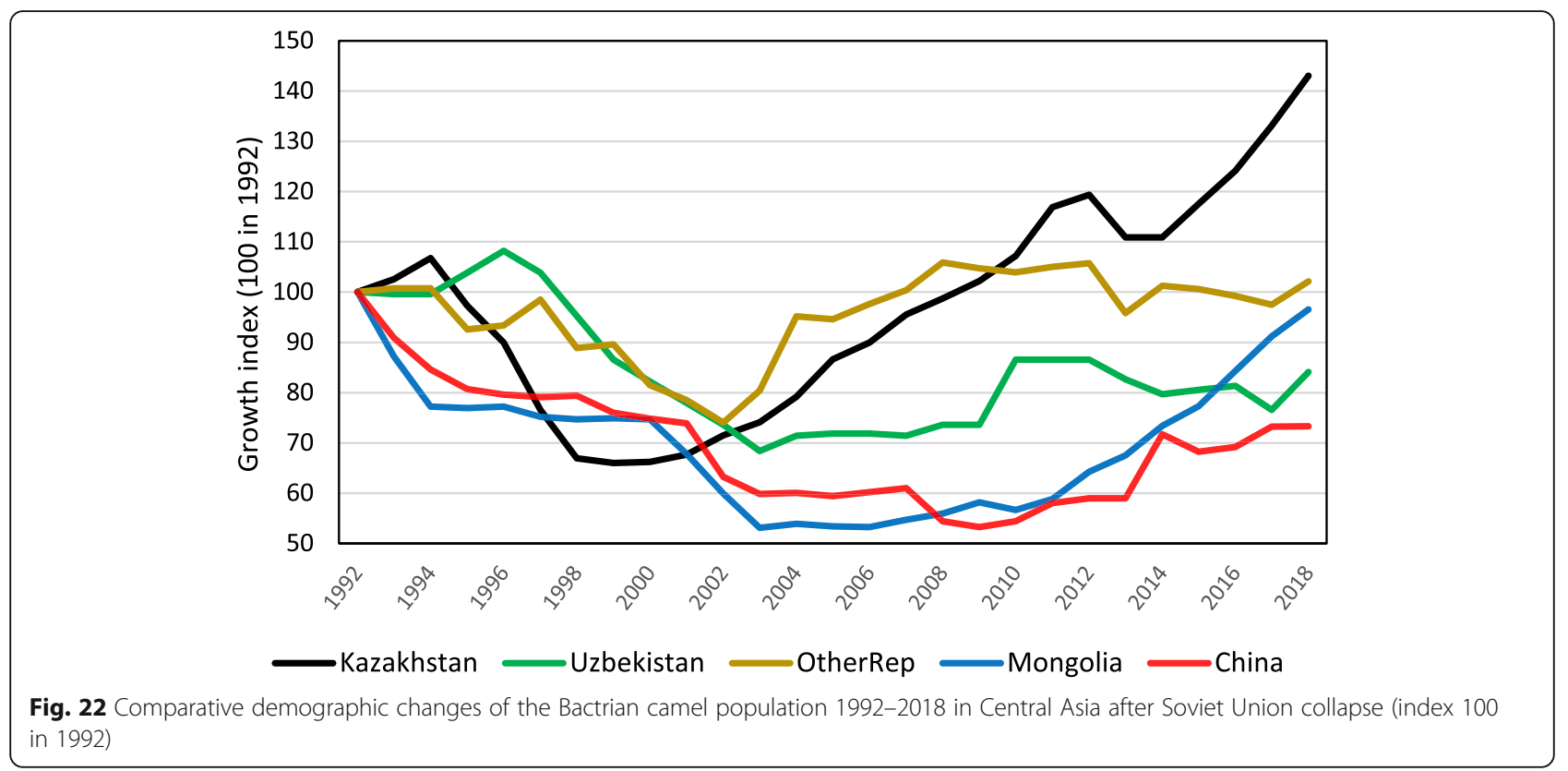

and Konuspayeva 2012; Digard 2019; Dioli 2020), the introgression of Bactrian genes into dromedaries was widely observed in camel populations where the two populations overlap (Burger 2016).

Consequently, estimating the exact number of the Bactrian camel population is not an easy task. Based on the data recorded in China, Mongolia, Russia, Kazakhstan (85\%) and other Central Asian Republics, there are probably fewer million domestic Bactrian camels now worldwide. Such a figure does not correspond exactly to the estimation of Bright et al. (2017) who stated that "according to incomplete statistics", the total number of Bactrian camels in the world would be around 2.8 million heads. Regarding the population changes occurring since 1961, a strong divergence was observed between the two large camelid species. While dromedary population increased annually on average by $3.8 \%$, Bactrian population decreased by $-0.10 \%$ (Fig. 19). The ratio Bactrian/dromedary at world level was $14 \%$ in 1961 and only $2.8 \%$ in 2018 (Fig. 20). The first sudden collapse in Bactrian numbers concurs with the collapse of the Soviet Union in 1991. The most important decline was observed in Kazakhstan (Fig. 21), where the camel stock went down from 145,100 heads in 1992 to 95,800 heads in 1999, the lowest value (Fig. 22). This fall linked to the privatization of the livestock sector in the country was, however, less tragic than the decimation subsequent to the collectivization operated by Stalin in the years 1927-1932 during which the camel stock declined by $90 \%$ going from 1.2 million heads to 120,000 only (Ohayon 2006; Faye and Konuspayeva 2020).

The decrease in camel population in Central Asia due to the changes in agricultural policies was compounded by the $d z u d$, a weather-related disaster occurring at the beginning of the year 2000 in Mongolia and China. The $d z u d$ is a catastrophic winter provoking a thick snow cover associated with intense cold with, in consequence, a frozen cover preventing livestock from grazing the winter pastures (Tachiiri et al. 2008). The main impact of the $d z u d$ on livestock was a significant over-mortality (Palat Rao et al. 2015) affecting all grazing species including camels (Otani et al. 2016). However, in all countries, positive changes have been recorded in the last 10 years, the lowest ratio Bactrian/dromedary occurring in 2008 when Bactrian camels represented only $2.2 \%$ of the dromedary stock.

\section{Scenario for the future}

If the global pattern between 1961 and 2018 related to the world camel population is maintained in the future, there is a strong likelihood that 50 million heads could be expected around the year 2030 and 60 million around 2045. However, the population changes are not dependent on natural camel herd growth alone. As analysed above, many of the steep rises observed in recent years have led to changes in extrapolation assumptions or revisions of earlier estimates. Trends of camel populations are also subject to the effects of climate changes, new implementations, new economic opportunities and political decision-making. Moreover, the analysis of those population trends does not take into account the changes in the camel farming systems marked by a tendency for "peri-urbanization", intensification and geographical expansion. Linked to the traditional 
nomadic way of life rooted in the past, camel pastoralism is currently under the pressure of important changes (Faye 2018).

\section{Conclusion}

Despite a probable underestimation of the worldwide camel population (estimated at around 40 million heads), its growth is higher than for the other herbivorous farm animals. Between 1961 and 2018, the world camel population multiplied by 2.75 , a higher value than equines (1.06), sheep (1.21), cattle (1.58), small camelids (1.72) and buffalo (2.33). Only the growth of the goat population appears higher (3.00). Such development testifies to the impact of climatic changes marked by widespread droughts in vast stretches of land in the world and of renewed interest in the camel within this new global climatic context. It also highlights the growing interest in camel products. However, in many countries, camel data are insufficiently recorded. Censuses are not common, and when they are performed, the number of camels appears inevitably higher than in previous estimations. Even in Western countries where all the livestock is identified, camels are not systematically registered. There is an urgent need to conduct an official count of the camel population worldwide and to distinguish between different camel species in FAO databases (FAOstat) in order to have a clear picture of their current status within the domestic herd. It is particularly important to accurately estimate the place of camel production in the world economy. There is enough evidence to suggest that this place should be strongly growing.

\section{Abbreviations \\ AHC: Ascending Hierarchical Classification; BJP: Bharatiya Janata Party (in India); CIRAD: Centre de Coopération Internationale pour la Recherche Agronomique en Développement; CSA: Central Statistics Authority: DHB: Domestic herbivorous biomass; GSA: General Statistics Authority; FAO: Food and Agriculture Organization of United Nations; FNDA: Fond National pour le Développement Agricole; NIS: New independent states; IGAD: Inter-Governmental Authority for Development; IUCN: International Union for Conservation of Nature; PDR: People's Democratic Republic; TCP: Tsabong Camel Park (in Botswana); TLU: Tropical livestock unit; USA: United States of America; USSR: Union of Soviet Socialist Republics}

\section{Acknowledgements}

This paper is supported by the PRIMA programme under grant agreement No1832, project "Boost the production, processing and consumption of camel milk in the Mediterranean basin (CAMELMILK)". The PRIMA programme is supported by the European Union. We acknowledge also Mrs. Mohammed Bengoumi and Thomas Schultze for proofreading the English version.

\section{Author's contributions}

BF extracted and analysed the data on live animals in FAO database and has written the manuscript. The author(s) read and approved the final manuscript.

\section{Author's information}

Dr. Bernard Faye is DVM, PhD and HDR, formerly head of Animal Production programme at CIRAD (France), FAO consultant in camel research and development, and at present independent expert on camel.

\section{Funding}

Not applicable, except for the partial payment of the publication fees by the communication budget from PRIMA project "CAMELMILK" (see the

"Acknowledgements" section).

\section{Availability of data and materials}

The datasets generated and analysed during the current study are available in FAOSTAT website: http://www.fao.org/faostat/en/\#data/QA.

\section{Ethics approval and consent to participate}

Not applicable. The author declares himself independent of the political entities described in this manuscript and declares that he does not take any personal political position which might not be suitable for nationals of these entities.

\section{Consent for publication}

Not applicable.

\section{Competing interests}

Not applicable.

Received: 10 May 2020 Accepted: 18 June 2020

Published online: 30 November 2020

\section{References}

Adamou, A. 2008. L'élevage camelin en Algérie: Quel type pour quel avenir ? Sécheresse 19 (4): 253-260. https://doi.org/10.1684/sec.2008.0149.

Adams, Christina. 2019. Camel crazy: A quest for miracles in the mysterious world of camels. Novato: New World Library.

Al-Ahmadi, K., S. Alahmadi, and A. Al-Zahrani. 2019. Spatiotemporal clustering of Middle East respiratory syndrome coronavirus (MERS-CoV) incidence in Saudi Arabia, 2012-2019. International Journal of Environmental Research and Public Health 16 (14): 2520. https://doi.org/10.3390/ijerph16142520.

Al-Haj, O. 2020. Exploring potential therapeutic properties of camel milk. In Handbook of research on health and environmental benefits of camel products, ed. Omar Alhaj, Bernard Faye, and Rajendra Agrawal, 123-154. Hershey: IGI Global.

Al-Jassim, R., and A. Lisle. 2016. Prediction and management of feral camel population in Australia. In Advances in conservation through sustainable use of wildlife. Proc. Conf. held in Brisbane, Australia, 30th August-1st September 2016, ed. Greg Baxter, Neal Finch, and Peter Murray, 74-77.

Asiimwe, R., J.H. Ainembabazi, A. Egeru, R. Isoto, D.K. Aleper, J. Namaalwa, and G. M. Diiro. 2020. The role of camel production on household resiulience to droughts in pastoral and agro-pastoral households in Uganda. Pastoralism: Research Policy and Practice 10: 5. https://doi.org/10.1186/s13570-020-0160-x.

Asres, A., and M. Yusuf. 2014. Traditional consumption, therapeutic value and its derived dairy products of dromedary camel (Camelus dromedaries) milk in Somali regional State, Eastern Ethiopia: A review. Journal of Biology, Agriculture and Healthcare 4 (25): 140-145.

Bonnet, P. 1996. Le cas des camelins autour du lac Tchad. In Atlas d'élevage du bassin du Lac Tchad [Livestock atlas of the Lake Chad Basin], ed. Isolde De Zborowski , 93-95. Wageningen: CTA.CIRAD-EMVT Service InfographieCartographie (FRA)

Bright, LY, H Jing, S Heller, and J Ri Mutu J. 2017. Progress in molecular genetics of Bactrian camel origin and evolution. Acta Ecologiae Animalis Domastici 38(3): 5-9.

Burger, P. 2016. The history of Old-World camelids in the light of molecular genetics. Tropical Animal Health and Production 48: 905-913. https://doi.org/ 10.1007/s11250-016-1032-7.

Burger, P., E. Ciani, and B. Faye. 2019. Old world camels in a modern world - A balancing act between conservation and genetic improvement. Animal Genetics. (Immunogenetic, Molecular Genetic \& Functional Genomic) 50: 598-612. https://doi.org/10.1111/age.12858.

Caliskan, V. 2016. A world cultural heritage: Anatolian camel dealing culture and camel wrestles. Ankara: Baski Publications. 
Diaz-Medina, E. 2017. Studies on identification, lactation and rearing of dromedaries in the island of Fuerteventura (Canary Islands). PhD thesis in animal sciences and nutrition. Barcelona: Autonomous University of Barcelona Publ.

Digard, J.P. 2019. Les hybrides chameau-dromadaire en Iran, entre technicité et ethnicité. Ethnozootechnie 106: 35-42.

Dioli, M. 2015. A brief history of the breeding of the camel (Camelus dromedarius) in Italy. In Proc. of the 3rd Camel Conference at SOAS, Univ. of London (UK), 9 -10th May 2015, 29-32.

Dioli, M. 2020. Dromedary (Camelus dromedarius) and Bactrian camel (Camelus bactrianus) crossbreeding husbandry practices in Turkey and Kazakhstan: An in-depth review. Pastoralism: Research, Policy and Practice 10: 6. https://doi.org/10.1186/s13570-020-0159-3.

Elzaki Ali, R.M., S.H. Ahmed, and M.A. Al-Mahish. 2018. Camel production in Kingdom of Saudi Arabia: Economic and environmental impacts. Fundamental and Applied Agriculture 3 (3): 602-608. https://doi.org/10.5455/faa.30229.

Ertürk, D. 2019. Media and tradition. In Third Intl. Selçuk-Ephesus symposium on culture-dealing and camel wrestling. Vol. I. Social sciences, ed. Atakan Koç and Öğretim Üyesi Hasan Erdogan, Selçuk Belediyesi Publ., 165-171. Selçuk: Selçuk Belediyesi. 17-19/01/2019.

Everitt, B.S., S. Landau, and M. Leese. 2001. Cluster analysis (4th edition). London: Arnold Publications.

FAOSTAT, 2020. http://www.fao.org/faostat/en/\#data/QA. Accessed 12 Apr 2020

Faye, B. 2013. Camel meat in the world. In Camel meat and meat products, ed. Isam Kadim, Osman Maghoub, Bernard Faye, and Mustafa Farouk, 7-16. Oxfordshire: CAB International.

Faye, B. 2015. Role, distribution, and perspective of camel breeding in the third millennium economies. Emirates Journal of Food and Agriculture 27 (4): 318 327. https://doi.org/10.9755/ejfa.v27i4.19906.

Faye, B. 2018. What future for camel pastoralism in the world? In Proc. of the 5th Conference ISOCARD "Recent advances in camelids biology, health and production", 12-15 Nov. 2018, ed. Abdelmalek Sghiri and Faouzi Kichou, 3238. Laâyoune: IAV Hassan II.

Faye, B. 2019. TADs in the dromedary (chapter 6). In Transboundary animal diseases in Sahelian Africa and connected regions, ed. Moustafa Kardjadj, Adama Diallo, and Renaud Lancelot, 91-110. Cham: Springer Nature.

Faye, B, O Abdelhadi, G Raiymbek, and I Kadim. 2013a. Filière viande de chameau et critère de qualité. Evolution du marché, perspectives de développement et qualité de la viande de chameau. Viandes \& Produits carnés. VPC-2013-296-2: 1-8, www.viandesetproduitscarnes.com.

Faye, B., and P. Bonnet. 2012. Camel sciences and economy in the world: Current situation and perspectives. In Proc. 3rd ISOCARD conference. Keynote presentations. 29th January -1st February 2012, Sultan Qaboos University Publ. , 2-15. Muscat.

Faye, B., and F. Brey. 2005. Les relations entre chameaux et société: Entre marginalisation et idéalisation. Revue d'Ethnozootechnie 77 -Varia: 43-50.

Faye, B., M. Chaibou, and G.F. Vias. 2012. Integrated impact of climate change and socioeconomic development on the evolution of camel farming systems. British Journal of Environment and Climate Change 2 (3): 227-244. https://doi.org/10.13140/2.1.2172.4164

Faye, B., J. Jaouad, K. Bhrawi, A. Senoussi, and M. Bengoumi. 2014. Elevage camelin en Afrique du Nord: État des lieux et perspectives. Revue d'Elevage et de Médecine Vétérinaire des Pays tropicaux 67 (4): 213-221. https://doi.org/ 10.19182/remvt.20563.

Faye, B., J.P. Jouany, J.P. Chacornac, and M. Ratovonanahary. 1995. L'élevage des grands camélidés. Analyse des initiatives réalisées en France. INRA Productions Animales 8: 3-17.

Faye, B., and G. Konuspayeva. 2012. The encounter between Bactrian and dromedary camels in Central Asia. In Camels in Asia and North-AfricaInterdisciplinary perspectives on their past and present significance, ed. EvaMaria Knoll and Pamela Burger, 27-33 (photos p.248-250). Wien: Austrian Academy of Sciences Press.

Faye, B., and G. Konuspayeva. 2020. Le chameau de Bactriane dans les vicissitudes de l'Histoire depuis 1917. In Les vaisseaux du désert et des steppes: Les camélidés dans l'Antiquité (Camelus dromedarius et Camelus bactrianus), ed. Damien Agut-Labordère and Bérangère Redon, 265-272. Lyon: Archéologies 2, MOM Editions.

Faye, B., G.F. Vias, and M. Chaibou. 2013b. Le dromadaire profite-t-il du changement climatique? Courrier de l'environnement de I'INRA 63: 131-140.

Fazal, M.A., M.R. Howlader, and M.A. Zaman. 2017. Productive and reproductive performances of camel (Camelus dromedarius) in Bangladesh. Journal of Veterinary Medicine and Surgery 1 (1): 5. https://doi.org/10.4172/2574-2868.100005.
Henrotay, D., and F. Pigière. 2012. Camels in the northern provinces of Roman Empire. Journal of Archaeological Science 39: 1531-1539. https://doi.org/10. 1016/j.jas.2011.11.014.

Imamura, K., R. Salmurzauli, M.K. Iklasov, A. Baibayssov, K. Matsui, and S.T. Nurtazin. 2017. The distribution of the two domestic camel species in Kazakhstan caused by the demand of industrial stockbreeding. Journal of Arid Land Studies 26: 233-236. https://doi.org/10.14976/jals.24.4_233.

Isani, GB, and MN Baloch. 2000. Camel breeds of Pakistan. In Arab Centre for the Studies of Arid Zones and Dry Lands, Pakistan Ministry of Food, Agriculture and Livestock and Camel Applied Research and Development Network (CARDN-Pakistan/ACSAD/P 94/2000), Syria: ACSAD publ., Damascus (Syria)

Islam, A., M.R. Islam, A.B.M. Ahmed Tanbir, S. Islam, and M.M.R. Howmlader. 2016. Prevalence of camel disease in Bangladesh: A retrospective study. International Journal of Natural Sciences 6 (1): 27-32.

Jahnke, H.E. 1982. Livestock production systems and livestock development in tropical Africa. Kiel: Wissenschaftsverlag Vauk Publ.

Jones, P., and A. Kenny. 2010. Australia's Muslim cameleers. Pioneers of the inland, 1860s-1930s. Mile End: Wakefield Press, South Australian Museum.

Jones, P.G., and P.K. Thornton. 2009. Croppers to livestock keepers: Livelihood transitions to 2050 in Africa due to climate change. Environmental Science \& Policy 12: 427-437. https://doi.org/10.1016/j.envsci.2008.08.006.

Kagunyu, A.W., and J. Wanjohi. 2014. Camel rearing replacing cattle production among the Borana community in Isiolo county of Northern Kenya, as climate variability bites. Pastoralism: Research, Policy and Practice 4: 13-18. https://doi.org/10.1186/s13570-014-0013-6.

Kebede, F., and E. Gelaye. 2010. Studies on major respiratory diseases of camel (Camelus dromedarius) in Northeastern Ethiopia. African Journal of Microbiology Research 4 (14): 1560-1564.

Kerven C., Alimaev I., Behnke K., Davidson G., Smailov A., Temirbekov S., Wright I., 2006. Fragmenting pastoral mobility: Changing grazing patterns in postSoviet Kazakhstan. In Rangelands of Central Asia: Transformations, issues and future challenges, ed. D. Bedunah, E. Mc Arthur and M. Fernandez-Gimenez. Fort Collins: Rocky Mountain Research Station Serial, US Dept of Agriculture.

Lethbridge, M., W. Keith, B. Saalfeld, and G.P. Edwards. 2016. Measured reductions in the density of camels under the Australian Feral Camel Management Project. The Rangeland Journal 38 (2): 173-179. https://doi.org/10.1071/RJ15106.

Makhdoomi, D.M., M.A. Gazi, S. Nabi, and S. Ahmed. 2013. Morphometric studies on adult double humped camel of Ladakh, India. Emirates Journal of Food and Agriculture 25 (7): 544-548. https://doi.org/10.9755/ejfa.v25i7.15999.

Marty, A., A. Eberschweiler, and Z. Dangbet. 2009. Au cœur de la transhumance. Un campement chamelier au Tchad central. Paris: Khartala.

Meena, A. 2018. Camel breeds of India: Contemporary overview. In 12th EuroGlobal Summit on Veterinary and Animal Sciences, Edinburgh (UK), 11-12 Oct. 2018. Journal of Veterinary Medicine and Surgery 2: 42. https://doi.org/10. 4172/2574-2868-C1-003.

Mirkena, T., E. Walelign, N. Tewolde, G. Gari, G. Abebe, and S. Newman. 2018. Camel production systems in Ethiopia: A review of literature with notes on MERSCOV risk factors. Pastoralism: Research, Policy and Practice 8 (30): 1-17. https://doi.org/10.1186/s13570-018-0135-3.

Niasari-Naslaji, A., D. Nikjou, J.A. Skidmore, A. Moghiseh, M. Mostafaey, K. Razavi, and A.A. Moosavi-Movahedi. 2009. Interspecies embryo transfer in camelids: The birth of the first Bactrian camel calves (Camelus bactrianus) from dromedary camels (Camelus dromedarius). Reproduction, Fertility and Development 21 (2): 333-337. https://doi.org/10.1071/RD08140.

Ohayon, I. 2006. La sédentarisation des Kazakhs dans I'URSS de Staline Collectivisation et changement social (1928-1945). Paris: Maisonneuve \& Larose-Institut Français d'Études sur l'Asie Centrale.

Otani, S., K. Onishi, Y. Kurozawa, Y. Kurosaki, T. Bat-Oyun, M. Shinoda, and H. Mu. 2016. Assessment of the effects of severe winter disasters (dzud) on public health in Mongolia on the basis of loss of livestock. Disaster Medicine and Public Health Preparedness 10 (4): 549-552. https://doi.org/ 10.1017/dmp.2016.5.

Palat Rao, M., N.K. Davi, R.D. D'Arrigo, J. Skees, B. Nachin, C. Leland, B. Lyon, S.U. Wang, and O. Byambasuren. 2015. Dzuds, droughts, and livestock mortality in Mongolia. Environmental Research Letters 10: 074012. https://doi.org/10.1088/ 1748-9326/10/7/074012.

Saalfeld, W.K., and G.P. Edwards. 2010. Distribution and abundance of the feral camel (Camelus dromedarius) in Australia. The Rangeland Journal 32: 1-9. https://doi.org/10.1071/RJ09058.

Schultz, U. 2008. El camello en Lanzarote. Arrecife: Asociación para el Desarrollo Rural de Lanzarote (ADERLAN) publication. 
Seifu, E., O.R. Madibela, and D. Teketay. 2019. Camels in Botswana: Herd dynamics and future development implications. Botswana Journal of Agriculture and Applied Sciences 13 (1): 12-25.

Smits, M.G., and G.J. Montety. 2009. Ammonia emission from camel dairy in the Netherlands. Journal of Camel Practice and Research 16 (2): 139-142.

Swai, E.S., W. Moshy, E. Mbise, J. Lutatina, and S. Bwanga. 2011 b. Disease and health conditions affecting camel production in pastoral and agro-pastoral communities of northern Tanzania. Research Opinions on Animal and Veterinary Sciences 1 (2): 83-88

Swai, E.S., W. Moshy, D. Mshanga, J. Lutatina, and S. Bwanga. 2011 a. Intestinal parasitic infections of camels in the agro- and pastoral areas of northern Tanzania. Veterinary Research 4: 34-38. https://doi.org/10.3923/vr.2011.34.38.

Tachiiri, K., M. Shinoda, B. Klinkenberg, and Y. Morinaga. 2008. Assessing Mongolian snow disaster risk using livestock and satellite data. Journal of Arid Environments 72 (12): 2251-2263. https://doi.org/10.1016/j.jaridenv.2008.06.015.

Tapper, R. 2011. One hump or two? Hybrid camels and pastoral cultures: An update. In Proc. of the Camel Conf. SOAS "Camel cultures: Historical traditions, present threats and future prospects", RN Books Publ.,149-162. London.

Tefera, M., and G. Abebe. 2012. The camel in Ethiopia. Addis-Ababa: Ethiopian Veterinary Association Publication

Tomczyk, W. 2016. Camels on the northeastern frontier of the Roman Empire. Papers from the Institute of Archaeology, University of Warsaw, 26(1): Art. 2, pp. 1-13. https://doi.org/10.5334/pia-485

Volpato, G., and E.G. King. 2019. From cattle to camels: Trajectories of livelihood adaptation and social-ecological resilience in a Kenyan pastoralist community. Regional Environmental Change 19: 849-865. https://doi.org/10. 1007/s10113-018-1438-z.

Wang, Z., W. Zhang, B. Wang, F. Zhang, and Y. Shao. 2018. Influence of Bactrian camel milk on the gut microbiota. Journal of Dairy Science 101 (7): 57585769. https://doi.org/10.3168/jds.2017-13860.

Wilson, R.T. 1984. The camel. London: Longman Publication.

Wilson, R.T. 2011. The one-humped camel and the environment in northern Tanzania. Journal of Camel Practice and Research 18 (1): 25-29.

Wilson, R.T. 2012. The one-humped camel in Southern Africa: Imports to and use in South-West Africa/Namibia. Journal of Camel Practice and Research 19 (1): 1-6.

Wilson, R.T. 2013. The one-humped camel in Southern Africa: Unusual and new records of seven countries in the Southern African Development Community. African Journal of Agricultural Research 8 (28): 3716-3723. https://doi.org/10.5897/AJAR12.2165.

Wilson, R.T. and Gutierrez C. 2015. The one-humped camel in the Canary Islands: History and present status. Tropicultura 33 (4): 288-298.

Wilson, R.T. 2017. The one-humped camel in Uganda. Journal of Camel Practice and Research 24 (1): 1-7.

Wilson, R.T. 2019. The one-humped camel in Bangladesh. Journal of Camel Practice and Research 26 (1): 11-13.

Yilmaz, O., and M. Ertugrul. 2014. Camel wrestling culture in Turkey. Turkish Journal of Agricultural and Natural Sciences, Special Issue 2: 1998-2005.

Yosef, T., U. Mengistu, A. Solomon, Y.K. Mohammed, and K. Kefelegn. 2013. Camel and cattle population dynamics and livelihood diversification as a response to climate change in pastoral areas of Ethiopia. Livestock Research for Rural Development 25 (9): 8

Young, J.A. 1982. Camels on the Western range. Rangelands 4 (6): 248-251.

Zarrin, M, JL Riveros, A Ahmadpour, AM De Almeida, G Konuspayeva, E Vargas-BelloPerez, B Faye, and LE Hernandez-Castellano. 2020. Camelids: New players in the international animal production context. Tropical Animal Health and Production 52: 903-913. https://doi.org/10.1007/s11250-019-02197-2.

Zeng, B., and M. McGregor. 2008. Review of commercial options for management of feral camels. In Managing the impacts of feral camels in Australia: A new way of doing business, ed. G.P. Edwards, B. Zeng, W.K. Saalfeld, P. VaarzonMorel, and M. McGregor, 221-282. Alice Springs: Desert Knowledge Cooperative Research Centre DKCRC Report 47.

\section{Publisher's Note}

Springer Nature remains neutral with regard to jurisdictional claims in published maps and institutional affiliations.

\section{Submit your manuscript to a SpringerOpen ${ }^{\circ}$ journal and benefit from:}

- Convenient online submission

- Rigorous peer review

- Open access: articles freely available online

- High visibility within the field

- Retaining the copyright to your article

Submit your next manuscript at $\boldsymbol{\nabla}$ springeropen.com 